\title{
Tissue-Resident T Cells in Chronic Relapsing-Remitting Intestinal Disorders
}

\author{
Juliana Barreto de Albuquerque *(D), Christoph Mueller $\mathbb{D}$ and Bilgi Gungor* \\ Division of Experimental Pathology, Institute of Pathology, University of Bern, 3008 Bern, Switzerland; \\ christoph.mueller@pathology.unibe.ch \\ * Correspondence: juliana.barretodealbuquerque@pathology.unibe.ch (J.B.d.A.); \\ bilgi.gungor@pathology.unibe.ch (B.G.)
}

\begin{abstract}
Tissue-resident memory $\mathrm{T}\left(\mathrm{T}_{\mathrm{RM}}\right)$ cells critically contribute to the rapid immunoprotection and efficient immunosurveillance against pathogens, particularly in barrier tissues, but also during anti-tumor responses. However, the involvement of $\mathrm{T}_{\mathrm{RM}}$ cells also in the induction and exacerbation of immunopathologies, notably in chronically relapsing auto-inflammatory disorders, is becoming increasingly recognized as a critical factor. Thus, $\mathrm{T}_{\mathrm{RM}}$ cells may also represent an attractive target in the management of chronic (auto-) inflammatory disorders, including multiple sclerosis, rheumatoid arthritis, celiac disease and inflammatory bowel diseases. In this review, we focus on current concepts of $\mathrm{T}_{\mathrm{RM}}$ cell biology, particularly in the intestine, and discuss recent findings on their involvement in chronic relapsing-remitting inflammatory disorders. Potential therapeutic strategies to interfere with these $\mathrm{T}_{\mathrm{RM}}$ cell-mediated immunopathologies are discussed.
\end{abstract}

Keywords: tissue-resident $\mathrm{T}$ cells; $\mathrm{T}$ cell retention; circulating $\mathrm{T}$ cells; memory $\mathrm{T}$ cells; intestinal inflammation

Citation: Barreto de Albuquerque, J.;

Mueller, C.; Gungor, B.

Tissue-Resident T Cells in Chronic Relapsing-Remitting Intestinal Disorders. Cells 2021, 10, 1882. https://doi.org/10.3390/ cells10081882

Academic Editor: Marc Basson

Received: 23 June 2021

Accepted: 21 July 2021

Published: 25 July 2021

Publisher's Note: MDPI stays neutral with regard to jurisdictional claims in published maps and institutional affiliations.

\section{Introduction}

Tissue-resident memory $\mathrm{T}\left(\mathrm{T}_{\mathrm{RM}}\right)$ cells mediate rapid immunosurveillance and immunoprotection during reinfection with potential pathogens. They show a distinct gene expression profile, which is remarkably conserved between mouse and human $\mathrm{T}_{\mathrm{RM}}$ cells [1,2], that distinguishes them from effector $\mathrm{T}$ cells and other memory $\mathrm{T}$ cell subsets. Although $\mathrm{T}_{\mathrm{RM}}$ cells are readily distinguished from other $\mathrm{T}$ cell subsets, with the increasing availability of single-cell RNA sequencing (scRNAseq) data, the heterogeneity of $\mathrm{T}_{\mathrm{RM}}$ cells in both human and mice $[3,4]$ is becoming obvious. $T_{R M}$ cells are the most abundant in barrier tissues, including mucosal tissues and the skin, which represent the main entrance sites for potential pathogens [5-7], and may also exert critical functions in $\mathrm{T}$ cell-mediated anti-tumor responses [8]. On the other hand, a critical involvement of $\mathrm{T}_{\mathrm{RM}}$ cells in the induction and exacerbation of immunopathologies, including inflammatory bowel diseases (IBD) and celiac disease, has been clearly identified [9-12].

Chronically relapsing inflammatory diseases in humans include debilitating disorders such as multiple sclerosis, rheumatoid arthritis, celiac disease and IBD. IBD is characterized by chronic inflammation of the gastrointestinal (GI) tract and includes Crohn's disease (CD), where any segment of the GI from the mouth to the anus can become affected; ulcerative colitis (UC), limited to the colon; and indeterminate colitis, when, at the time of diagnosis, a distinction between $\mathrm{CD}$ and $\mathrm{UC}$ is not (yet) possible $[13,14]$. The disease course is clinically characterized by episodes of active disease, which may become quiescent after therapy, and spontaneous relapse within months to years [15-17]. Current evidence suggests that inflammatory bowel diseases result from an inappropriate inflammatory immune response to intestinal microbe-derived antigens in a genetically susceptible host [18]. IBDs are chronic, lifelong diseases, which severely affect physical, psychological and social aspects of life and, thus, have a major impact on quality of life [14]. An estimated $25-40 \%$ of 
patients with IBD will also develop extra-intestinal manifestations during their lifetime [19]. At 30 years following the first diagnosis, $50 \%$ of patients experience at least one extraintestinal manifestation [20]. Despite enormous efforts and considerable progress in our understanding of the pathogenic mechanisms, which also resulted in novel concepts of treating patients with IBD to allow for prolonged remission periods, there is currently still no cure for UC or CD [14]. Therefore, new candidate treatments that allow us to further delay, or even prevent, relapses of these debilitating disorders are needed. Furthermore, the insight gained into the pathophysiology of IBD may further our understanding also of the pathogenetic mechanisms operative in other chronic inflammatory diseases [21].

Celiac disease $(\mathrm{CeD})$, as another relevant chronic relapsing-remitting disease of the intestine, is caused by an abnormal small intestinal $\mathrm{T}$ cell response to gluten, which is the major storage protein of wheat and related cereals. The disease has a strong MHC (HLA) association, and $\mathrm{CD} 4^{+} \mathrm{T}$ cells recognizing gluten epitopes presented by disease-associated HLA- molecules (mostly, HLA-DQ2.5, but also HLA-DQ8 or HLADQ2.2) are considered to be the critical drivers of the disease [22]. Originally, CeD was believed to represent a rare malabsorption syndrome in children and teenagers. However, it is now increasingly recognized as a common condition that may be diagnosed at any age.

A gluten-free diet is key for a successful therapy; however, relapse of the disease is seen in a considerable fraction (up to $30 \%$ ) of CeD patients, mainly due to dietary non-adherence [23]. In contrast to the huge variety of intestinal lumen-derived microbial antigens as triggers of the disease in IBD, in $\mathrm{CeD}$, the triggering antigen, i.e., the dietary protein gluten, modified by the host-derived enzyme tissue transglutaminase, is well characterized [24].

This review focuses on the biology of $\mathrm{T}_{\mathrm{RM}}$ cells, with special emphasis on their involvement in chronic intestinal inflammation. Furthermore, we also discuss their potential as targets in the management of chronic relapsing-remitting inflammatory disorders, particularly when $\mathrm{T}_{\mathrm{RM}}$ cell-specific pathways can be manipulated.

\section{Tissue-Resident Memory $T$ Cell Subsets in the Intestine}

Naïve $T$ cells are activated in intestine-draining lymph nodes by antigen-loaded dendritic cells that migrate to these sites following antigen uptake in the intestinal mucosa. Most of these activated T cells are instructed by the local environment to express tissue-specific chemokine receptors, notably CCR9, to migrate back to the site of antigen entry [25]. In the local microenvironment of the intestinal mucosa, they may subsequently differentiate into local $\mathrm{T}_{\mathrm{RM}}$ cells to become an integral part of the immune sensing network. They monitor the tissues for local perturbations in homeostasis and are involved in the immunosurveillance against infection and cancer, but are increasingly recognized as promotors of immunopathologies [26]. During a local reinfection, $\mathrm{T}_{\mathrm{RM}}$ cells rapidly exert their immune functions, such as cytotoxic effector functions, or the secretion of chemokines, to amplify locally the adaptive and innate immune response against pathogens, thus critically contributing to immunosurveillance and immunoprotection [27-29] (Figure 1).

In the intestinal mucosa, $\mathrm{T}_{\mathrm{RM}}$ cells are found in both the intestinal epithelium ("intraepithelial lymphocytes", IEL) and in the lamina propria ("lamina propria lymphocytes", LPL). These two compartments are only separated by the basement membrane; their cellular composition, however, differs considerably. In the mouse intestine, CD8 $\alpha \alpha^{+}$and CD8 $\alpha \beta^{+}$ $\mathrm{TCR} \alpha \beta^{+} \mathrm{T}$ cells, together with TcR $\gamma \delta^{+} \mathrm{T}$ cells, dominate in the IEL compartment [30]. CD $8 \alpha \alpha^{+} \mathrm{TCR} \alpha \beta^{+} \mathrm{T}$ cells and TCR $\gamma \delta^{+} \mathrm{T}$ cells are considered unconventional IEL [31]. In contrast to conventional CD4 $4^{+}$and $\mathrm{CD} 8 \alpha \beta^{+} \mathrm{TCR} \alpha \beta^{+} \mathrm{T}$ cells, in the mouse, the unconventional CD8 $\alpha \alpha^{+} \mathrm{TCR} \alpha \beta^{+} \mathrm{T}$ cells and TCR $\gamma \delta^{+} \mathrm{T}$ cells do not undergo an intrathymic negative selection [32] and may leave the thymus before this differentiation program is initiated. At a transcriptional (and functional) level, intestinal CD8 $\alpha \alpha^{+} \mathrm{TCR} \alpha \beta^{+}$IEL are thus more related to TCR $\gamma \delta^{+}$IEL than to CD $8 \alpha \beta^{+}$TCR $\alpha \beta^{+}$IEL [33]. 


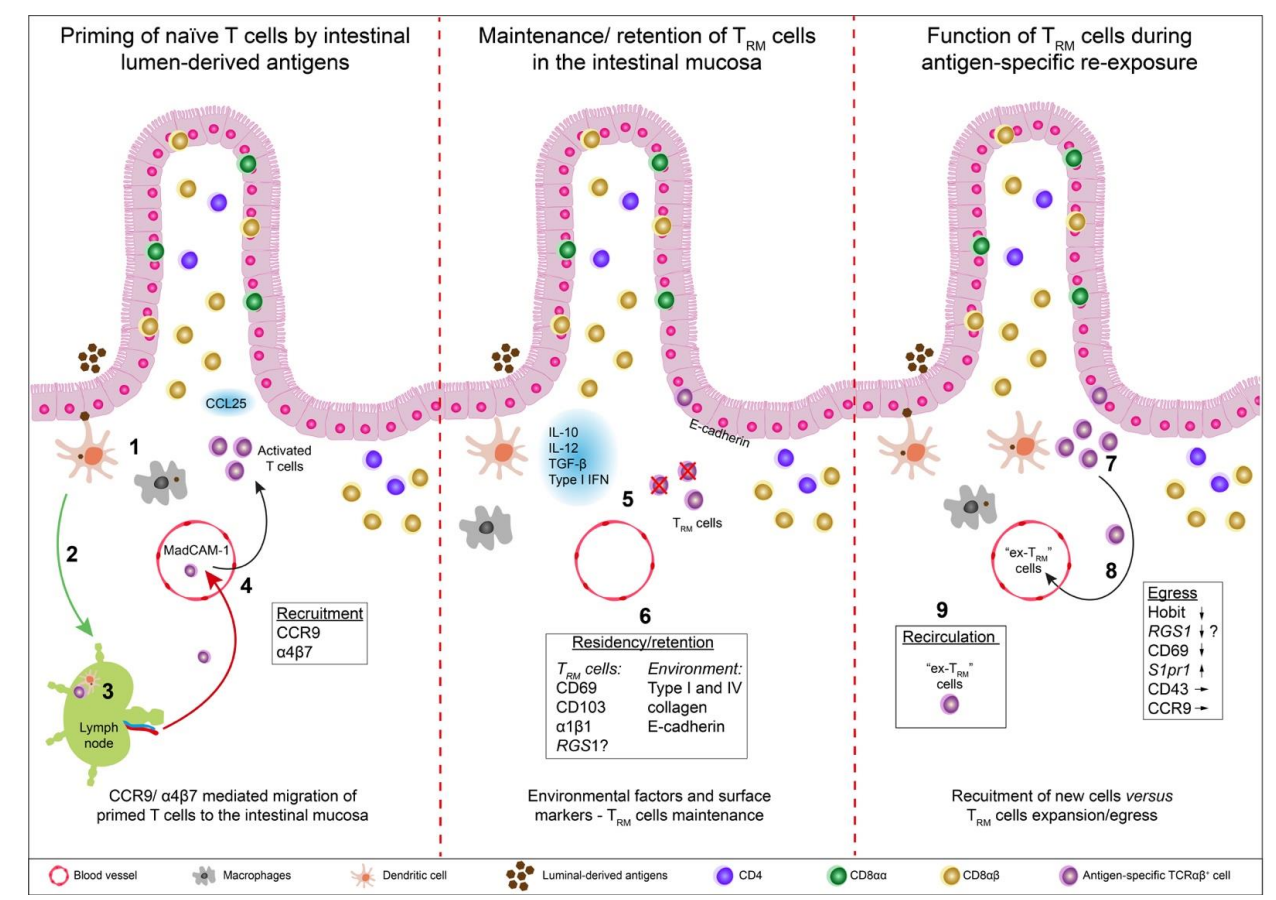

Figure 1. Activation of conventional intestinal T cells following primary exposure to a novel, MHC-restricted antigen versus re-exposure of $\mathrm{T}_{\mathrm{RM}}$ cells to their cognate antigen. (1) Intestinal lumen-derived antigens (microbiota, food antigens, pathogens) breach the intestinal epithelial barrier through specialized M cells overlying intestinal Peyer's patches and solitary follicles (not shown), or obtain access to the intestinal lamina propria when the integrity of the epithelial layer is disrupted. Inside the lamina propria, antigens are rapidly taken up and digested by local macrophages, which are rather poor antigen-presenting cells. A fraction of the intestinal lumen-derived antigens, however, is sampled by intestinal dendritic cells. (2) These antigen-loaded dendritic cells become activated and migrate to the draining mesenteric lymph nodes, (3) where they present the antigen in an MHC-restricted manner to antigen-specific naïve CCR7 ${ }^{+} \mathrm{CD}_{2} \mathrm{~L}^{+} \mathrm{T}$ cells. $(4)$ Upon their priming in the draining lymph nodes, these activated T cells acquire a gut homing phenotype, characterized by the cell surface expression of $\alpha 4 \beta 7$ and CCR9, which bind to MadCAM- 1 expressed on gut-associated endothelial cells, and to the chemokine CCL25, secreted by endothelial cells in the small intestine and by follicle-associated epithelium of Peyer's patches, respectively. This imprinted phenotype allows the primed T cells to home back to the site of initial antigen breaching. (5) Under the influence of the local intestinal microenvironment (e.g., TGF- $\beta$, IL-12 and type-I IFN), some of these recently activated $\mathrm{T}$ cells acquire a $\mathrm{T}_{\mathrm{RM}}$ cell signature. (6) Within the intestinal mucosa, transcription of the $\alpha 4$ chain gene is suppressed in T cells. TGF- $\beta$, secreted by macrophages and dendritic cells, induces the expression of $\alpha \mathrm{E}$ integrin (CD103). The $\alpha \mathrm{E} \beta 7$ heterodimer binds to E-cadherin, which is expressed on epithelial cells and subsets of dendritic cells. Subsets of $\mathrm{CD}^{+} \mathrm{T}_{\mathrm{RM}}$ cells also express the integrin $\alpha 1$ chain together with the $\beta 1$ integrin $(\alpha 1 \beta 1)$, which directly binds to type I and IV collagen and, hence, supports the adherence and retention of $\mathrm{T}_{\mathrm{RM}}$ cells in skin, lung and intestine. Most $\mathrm{T}_{\mathrm{RM}}$ cells also express $\mathrm{CD} 69$, which antagonizes $\mathrm{S1P}_{1}$ (Sphingosine 1 phosphate receptor-1), thus contributing to their retention within the tissue. RGS1, which attenuates signaling via G $\alpha$ i- or G $\alpha$ q- linked G-protein-coupled receptors, is also highly expressed in $\mathrm{T}_{\mathrm{RM}}$ cells. This signature allows them to remain at this site even upon complete clearance of their cognate antigen. These newly generated $\mathrm{T}_{\mathrm{RM}}$ cells will thus continuously expand the existing repertoire of antigen specificities of the local $\mathrm{T}_{\mathrm{RM}}$ cells. Some of these activated $\mathrm{T}_{\mathrm{RM}}$ cells (mostly CD $8 \alpha \beta^{+} \mathrm{TCR} \alpha \beta^{+}, \mathrm{CD} 8 \alpha \alpha^{+} \mathrm{TCR} \alpha \beta^{+}$and TCR $\gamma \delta^{+}$cells) will home to the intestinal epithelium ("intraepithelial lymphocytes"), where they are preferentially retained by the interaction of the $\alpha \mathrm{E} \beta 7$ integrin on their surface with epithelial cell-expressed E-cadherin. (7) Upon re-exposure to the cognate antigen, $\mathrm{T}_{\mathrm{RM}}$ cells are rapidly activated and expand locally in the mucosa. They are prone to efficiently secrete cytokines and express cell surface molecules, which may further enhance the uptake and degradation of incoming microbes or dietary compounds by local (resident) macrophages. Reactivated $\mathrm{T}_{\mathrm{RM}}$ cells may express cytotoxic effector molecules, including granzymes and perforin, or secrete chemokines that promote the recruitment of other leukocyte subsets, including monocytes, but also effector $\mathrm{T}$ cells. (8) Additionally they can loose some $\mathrm{T}_{\mathrm{RM}}$ cell markers and retention profile (Hobit, CD69, and potentially RGS1) and upregulate genes related to egress (S1pr1). (9) Thus, eventually, they can re-enter the blood circulation as "ex- $\mathrm{T}_{\mathrm{RM}}$ " cells, becoming circulating effector cells and memory $\mathrm{T}$ cells, thus, supporting also the systemic immune response. 
In the intestinal lamina propria, the distribution of $\mathrm{T}$ cells more closely resembles the composition of lymphoid organs. $\mathrm{CD}^{+} \mathrm{T}$ cells represent the predominant intestinal lamina propria T cell subset in both the small and large intestine, unconventional CD8 $\alpha \alpha^{+}$ $\mathrm{TCR} \alpha \beta^{+} \mathrm{T}$ cells are absent, and TCR $\gamma \delta^{+} \mathrm{T}$ cells are present only at lower frequencies than in the IEL compartment [34,35]. Gut-associated lymphoid tissues, such as Peyer's patches, colonic patches and solitary lymphoid follicles, are embedded within the intestinal lamina propria and form organized induction sites together with the draining lymph nodes, which act as an immunological firewall for intestinal lumen-derived antigens to allow for an efficient adaptive immune response [36,37].

\section{Differentiation of T Cells after Initial Antigen Exposure}

$\mathrm{CD} 8^{+} \mathrm{T}$ cells expand and differentiate upon initial antigen-specific priming into phenotypically distinct subsets. Early after antigen-exposure, early effector T cells (EECs) dominate the initial antigen-specific $\mathrm{T}$ cell response. EECs lack cell surface expression of the IL-7 receptor- $\alpha$ chain (CD127) and of the killer lectin-like receptor 1 (KLRG1). Intriguingly, a single naïve CD8 T cell may give rise to different fates, and may also further differentiate into memory precursor effector cells (MPECs), characterized by a CD127 $7^{+}$ KLRG1 ${ }^{-}$phenotype, and CD127 ${ }^{-} \mathrm{KLRG1}^{+}$short-lived effector cells (SLECs) $[38,39]$. SLECs are responsible for the rapid, high-affinity $\mathrm{CD}^{+} \mathrm{T}$ cell-mediated immune response [40,41] On the other hand, $\mathrm{KLRG}^{-} \mathrm{CD} 127^{+}$MPECs further differentiate into circulating memory and resident memory T cells [42]. TCR affinity appears to regulate the generation of MPECs versus SLECs: intriguingly, T cells with a high-affinity TCR appear to be prone to develop into SLECs, while T cells with an intermediate-affinity TCR preferentially differentiate into MPECs, possibly reflecting a "trade-off" between the rapid expansion of high-affinity T cells versus the long-term production of intermediate-affinity $\mathrm{T}$ cells $[43,44]$. In an acute influenza infection model, $\mathrm{CD} 8^{+} \mathrm{T}$ cells with a high-affinity $\mathrm{TCR}$ were more prone to differentiate into SLECs, while T cells with a lower-affinity TCR in this mouse model preferentially differentiated into $\mathrm{CD} 8^{+} \mathrm{T}_{\mathrm{RM}}$ cells or $\mathrm{CD} 8^{+} \mathrm{T}_{\mathrm{EM}}$ cells [45]. Extrinsic factors may also direct the fate of $\mathrm{CD} 8^{+} \mathrm{T}$ cells even before initial cognate antigen recognition: TGF- $\beta$ produced by migratory dendritic cells in draining lymph nodes can epigenetically condition naïve CD8 $\mathrm{T}$ cells to differentiate into epidermal $\mathrm{T}_{\mathrm{RM}}$ cells upon intradermal vaccination with a plasmid-encoding chicken ovalbumin [46]. Accordingly, the route of pathogen entry also appears to influence the homing of the precursors and $\mathrm{T}_{\mathrm{RM}}$ cell differentiation. For instance, $\mathrm{CD} 8^{+} \mathrm{T}_{\mathrm{RM}}$ cells in the intestinal epithelium were activated by oral infection with Listeria monocytogenes, but not by infection via the intranasal or intravenous routes [47]. Hence, the local cytokine milieu present at the site of antigen priming appears to be a critical factor to direct the generation of $\mathrm{T}_{\mathrm{RM}}$ cells in barrier tissues. In this respect, the cytokines TGF- $\beta$, IL-15, IL-12 and type-I IFN are critical in the early phase of $\mathrm{T}_{\mathrm{RM}}$ cell differentiation [1,48] (Figure 1).

\section{Retention of $T_{\mathrm{RM}}$ Cells in the Intestinal Mucosa}

$\mathrm{T}_{\mathrm{RM}}$ cells were operationally identified in parabiosis experiments, where, in contrast to the circulating $\mathrm{T}$ cell subsets, $\mathrm{T}_{\mathrm{RM}}$ cells were not shared among the two parabiotic partners in short-term parabiosis experiments [49-52]. The development and functional differentiation of $\mathrm{T}_{\mathrm{RM}}$ cells includes several checkpoints, including the entry into their target tissues, local retention and subsequent responsiveness to local cytokines and other factors that support $\mathrm{T}_{\mathrm{RM}}$ cell formation and survival [53].

Hence, it is not surprising that the transcriptional signatures of $T_{R M}$ cells in humans and in mice are distinct from naïve $\mathrm{T}$ cells, $\mathrm{T}_{\mathrm{CM}}$, and $\mathrm{T}_{\mathrm{EM}}$ cells. The core $\mathrm{T}_{\mathrm{RM}}$ cell signatures are remarkably consistent in $\mathrm{T}_{\mathrm{RM}}$ cells from different barrier tissues in mice and humans [2,54-56], although functional heterogeneities are increasingly observed among $\mathrm{T}_{\mathrm{RM}}$ cell populations within the same tissue, particularly upon scRNAseq analyses $[4,55]$. Most of these $\mathrm{T}_{\mathrm{RM}}$ cell signature genes encode proteins with a direct, or indirect, involvement in the retention and prolonged maintenance in the tissue as long-lived $\mathrm{T}_{\mathrm{RM}}$ cells [42]. 
Furthermore, $\mathrm{T}_{\mathrm{RM}}$ cells are also characterized by the expression of genes (e.g., Bhlhe40) which enhance their metabolism by conferring increased mitochondrial fitness, while the expression of distinct genes which are overexpressed in $\mathrm{T}_{\mathrm{CM}}, \mathrm{T}_{\mathrm{EM}}$, or $\mathrm{T}_{\mathrm{EFF}}$ cells is completely absent in $\mathrm{T}_{\mathrm{RM}}$ cells, such as KLRG1, CCR7, $\mathrm{S1P}_{1}$ and KLF2 (Table 1).

Table 1. Phenotypic signatures of conventional intestinal $\mathrm{T}_{\mathrm{RM}}$ cells.

\begin{tabular}{|c|c|c|c|c|}
\hline & Markers & $\begin{array}{c}\mathrm{CD} 4^{+} \mathrm{TCR} \alpha \beta^{+} \\
\mathrm{T}_{\mathrm{RM}} \text { Cells }\end{array}$ & $\begin{array}{c}\mathrm{CD} 8 \alpha \beta^{+} \mathrm{TCR} \alpha \beta^{+} \\
\mathrm{T}_{\mathrm{RM}} \text { Cells }\end{array}$ & References \\
\hline \multirow{8}{*}{ Differentiation } & T-bet & + & + & {$[1,54]$} \\
\hline & Eomes & - & - & [1] \\
\hline & KLRG1 & - & - & {$[42,47,57,58]$} \\
\hline & CD127 & ++ & ++ & {$[57,58]$} \\
\hline & TCF7 & + & + & {$[54,59]$} \\
\hline & Hobit & +++ & +++ & {$[9,54]$} \\
\hline & Blimp1 & +++ & +++ & {$[9,54]$} \\
\hline & Runx3 & + & +++ & {$[60]$} \\
\hline \multirow{10}{*}{$\begin{array}{l}\text { Migration/ } \\
\text { Retention }\end{array}$} & $\mathrm{S}_{\mathrm{P}} \mathrm{P}_{1}$ & - & - & {$[2,59,61]$} \\
\hline & KLF2 & - & - & {$[2,59]$} \\
\hline & CD69 & +++ & +++ & {$[2,42,54,61]$} \\
\hline & CD103 & ++ & +++ & {$[2,9,62]$} \\
\hline & $\alpha 4 \beta 7$ & ++ & +++ & {$[29,63]$} \\
\hline & $\mathrm{CD} 49 \mathrm{a}$ & +++ & +++ & {$[57,64]$} \\
\hline & CCR7 & - & - & {$[57,58]$} \\
\hline & $\begin{array}{c}\text { CD62L } \\
\text { (L-selectin) }\end{array}$ & - & - & {$[2,42]$} \\
\hline & CXCR6 & +++ & +++ & {$[2,9]$} \\
\hline & RGS1 & ++ & +++ & {$[2,65]$} \\
\hline \multirow{4}{*}{$\begin{array}{l}\text { Metabolic } \\
\text { Markers }\end{array}$} & Ahr & +++ & +++ & [66] \\
\hline & Bhlhe40 & ++ & ++ & [67] \\
\hline & P2XR7 & +++ & +++ & [68-70] \\
\hline & $\mathrm{HIF} 1 \alpha$ & +++ & +++ & [71] \\
\hline
\end{tabular}

Relative expression of the indicated markers, $(-)$, absent in all cells; $(+)$ low frequency of expressing cells; $(++)$ intermediate frequency (or expression level), $(+++)$ high frequency (or expression level).

In humans and mice the recruitment of circulating $\mathrm{T}$ cell subsets to mucosal sites is directed by the integrin $\alpha 4 \beta 7$, which becomes expressed in EEC subsets upon antigen-specific activation at inductive sites. This integrin binds to the mucosal addressin MadCAM-1, and, hence, is most critical for the recruitment of $\mathrm{T}$ cells to mucosal sites. Upon diapedesis of $\alpha 4 \beta 7$-expressing T cells into mucosal sites, the transcription of the Itga4 gene is suppressed and the expression of Itgae is induced by bioactive TGF- $\beta$, which is present locally at elevated levels, resulting in an exchange of the $\alpha 4$-integrin chain by the $\alpha \mathrm{E}$ integrin (CD103). The $\alpha \mathrm{E} \beta 7$ heterodimer binds to E-cadherin, which is expressed on epithelial cells [72], but also on haematopoietic cells, including inflammatory dendritic cells in draining lymph nodes [73]. CD103 expression is more prominent in CD8 ${ }^{+} \mathrm{T}_{\mathrm{RM}}$ cells than in $\mathrm{CD} 4^{+} \mathrm{T}_{\mathrm{RM}}$ cells in both humans and mice [62]. Oral infection studies with Listeria monocytogenes revealed that CD103 is indeed essential for the local accumulation of the CD8 ${ }^{+} \mathrm{T}$ cells in the small intestine epithelium and LP, yet, is dispensable for T cell retention [29,47]. However, also $\mathrm{CD} 13^{-} \mathrm{CD}^{+} \mathrm{T}_{\mathrm{RM}}$ cells were found, notably in the intestinal lamina propria after Yersinia pestis infection [62], and the size of this $\mathrm{CD} 103^{-} \mathrm{CD}^{+} \mathrm{T}_{\mathrm{RM}}$ cell population appears to be 
TGF- $\beta$-independent, but is critically regulated by IFN- $\gamma$ and IL-12 [48]. Subsets of CD8 ${ }^{+}$ $\mathrm{T}_{\mathrm{RM}}$ cells also express the integrin $\alpha 1$ chain $(\mathrm{CD} 49 \mathrm{a})$, together with the $\beta 1$ integrin $(\alpha 1 \beta 1)$, which directly binds collagen type I and IV and, hence, supporting the adherence and retention of $\mathrm{T}_{\mathrm{RM}}$ cells in the skin, lung and intestine [64,74] (Table 1, Figure 1).

Sphingosine-1-phosphate receptor $\left(\mathrm{S}_{1} \mathrm{P}_{1}\right)$ is a critical checkpoint for $\mathrm{T}_{\mathrm{RM}}$ cell persistence [27]. It facilitates $\mathrm{T}$ cell exit out of lymph nodes in response to higher S1P levels within the efferent lymph [75]. S1P 1 expression is regulated by the transcription factor Kruppel-like factor 2 (KLF2), and $\mathrm{S}_{1} \mathrm{P}_{1}$ signaling is antagonized by CD69, a type II-C lectin receptor [61], which is part of the $\mathrm{T}_{\mathrm{RM}}$ cell signature, but is also transiently upregulated on $\mathrm{T}$ cells upon antigen-specific activation [76]. Similar to $\mathrm{T}_{\mathrm{RM}}$ cells from other mucosal tissues, intestinal $\mathrm{T}_{\mathrm{RM}}$ cells decrease the expression of KLF2 and upregulate CD69 upon migration to their site of residence. This differential expression of KLF2 and CD69 suppresses $\mathrm{S}_{1} \mathrm{P}_{1}$ responsiveness and restrains the $\mathrm{T}_{\mathrm{RM}}$ cells in the tissues [77]. Although CD69 is commonly believed to represent a surrogate marker for the identification of $\mathrm{T}_{\mathrm{RM}}$ cells, some recent reports suggest that CD69 is dispensable for $\mathrm{T}_{\mathrm{RM}}$ cell formation and maintenance in some barrier tissues, including the small intestine, lung and female reproductive tract [78]. Moreover, deletion of CD69 in mice does not affect CD4 ${ }^{+} \mathrm{T}_{\mathrm{RM}}$ cell formation, while the frequencies and numbers of $C D 8^{+} \mathrm{T}_{\mathrm{RM}}$ cells in the skin and lung were reduced after influenza virus infection in CD69-deficient mice, indicating a differential requirement for $\mathrm{CD} 69$ for the retention of $\mathrm{CD}^{+}$versus $\mathrm{CD} 8 \alpha \beta^{+} \mathrm{T}$ cells, which may further be influenced by the site of residency [42].

Similar to $\mathrm{S}_{1} \mathrm{P}_{1}$, the chemokine receptor CCR7 is upregulated by KLF2 and downregulated in $\mathrm{T}_{\mathrm{RM}}$ cells. It guides mostly naïve T cells along a CCL21 and CCL19 gradient into the $\mathrm{T}$ cell zone of secondary lymphoid organs. The absence of CCR7 expression on $\mathrm{T}_{\mathrm{RM}}$ cells likely prevents their migration out of the intestinal mucosa to the CCL19 and/or CCL21 containing afferent lymphatics [61]. Furthermore, the gut homing receptors CCR6 and CCR9 are upregulated in $\mathrm{T}_{\mathrm{RM}}$ cells to retain both $\mathrm{CD}^{+}$and $\mathrm{CD} 8^{+} \mathrm{T}$ cells at these mucosal sites, with elevated levels of their corresponding ligands CCL20 (expressed in the small intestine) and CCL25 (expressed in the small and large intestine), respectively $[2,4,79,80]$. Hence, also the responsiveness of $\mathrm{T}$ cells to chemokines in barrier tissues (and the mode of their regulation) is critical for defining the retention of $\mathrm{T}_{\mathrm{RM}}$ cells in the tissue. Some members of the the regulator of G protein signaling (RGS) family, including RGS1, are consistently overexpressed in $\mathrm{T}_{\mathrm{RM}}$ cells from barrier tissues [65,81-83], but also in tumorinfiltrating T cells $[84,85]$. These RGS family members enhance the GTPase activity of

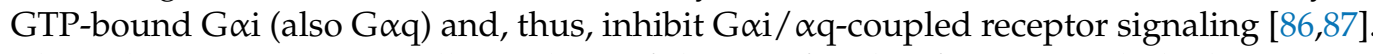

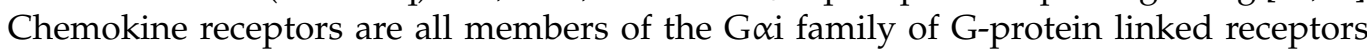
(GPCR); thus, RGS1 is considered a potential repressor of chemokine-mediated T cell egress and supports local $\mathrm{T}_{\mathrm{RM}}$ cells retention in the gut. The capacity of RGS1 to regulate directional chemotaxis was confirmed in trans-well experiments with CCR7 and CXCR4 expressing Jurkat cells, which, upon transfection with the RGS1 gene, displayed impaired migration to the lymph node chemokines CCL19 (ligand for CCR7) and CXCL12 (ligand for CXCR4) [65].

The local cytokine microenvironment in the intestinal mucosa critically shapes intestinal $\mathrm{T}_{\mathrm{RM}}$ cell differentiation and tissue retention. Bioactive TGF- $\beta$ is present in many epithelial surfaces, including the small and large intestinal epithelium, and promotes CD103 expression on $\mathrm{T}_{\mathrm{RM}}$ precursor cells, which allows the enhanced retention of $\mathrm{T}_{\mathrm{RM}}$ cells in e-cadherin-expressing epithelia $[29,42,47]$. TGF- $\beta$ is produced and secreted as a biologically inactive precursor bound to the latency associate peptide. This biologically inactive complex is stored in the extracellular matrix before it is processed and cleaved to release its biologically active form of TGF- $\beta$. This is achieved by integrin-dependent and -independent mechanisms. The extracellular processing of the latent TGF- $\beta$ complex represents a key element in the regulation of TGF- $\beta$ activity. Integrin-independent mechanisms of TGF- $\beta$ processing may include proteolytic cleavage, lower $\mathrm{pH}$ and thrombospondininduced cleavage, while $\alpha \mathrm{V} \beta 6$ and $\alpha \mathrm{V} \beta 8$ integrins are responsible for integrin-mediated 
TGF- $\beta$ processing [88]. The preferential expression of these integrins in epithelia may thus represent a critical factor for controlling the retention of local resident cell subsets in epithelial tissues [89]. Indeed, in the skin, competition for active TGF- $\beta$ allows the selective retention of antigen-specific $\mathrm{T}_{\mathrm{RM}}$ cells in the epidermal niche [90].

Downregulation of both T-box transcription factors T-bet/Tbx21 and Eomes represents-at least in the skin-a critical step in the local differentiation of $\mathrm{CD} 8^{+} \mathrm{CD} 103^{+} \mathrm{T}_{\mathrm{RM}}$ cells. TGF- $\beta$-signaling downregulates the expression of these T-box transcription factors, while, conversely, T-bet and Eomes downregulation are a prerequisite for TGF- $\beta$ cytokine signaling. In the complete absence of Eomes expression, however, skin $\mathrm{CD} 8^{+} \mathrm{CD} 103^{+} \mathrm{T}$ cells become dependent on residual T-bet expression, which controls the expression of CD122 (IL-15RB), and hence the responsiveness of $\mathrm{T}_{\mathrm{RM}}$ cells to IL-15. IL-15 signaling appears to be critical for the survival and maintenance of $T_{R M}$ cells in the skin, lungs, liver, salivary glands and kidney, whereas in the small intestinal mucosa of mice, $T_{R M}$ cells proliferate and persist even in the absence of IL-15 [1,91]. In mice, the transcription factor "homolog of blimp1" (Hobit), encoded by the Znf683 gene and Blimp1, encoded by the Prdm1 gene, control the expression of CD69, KLF2 and $\mathrm{S1P}_{1}$, which are critically required for $\mathrm{CD}^{+}$and $\mathrm{CD}^{+} \mathrm{T}_{\mathrm{RM}}$ cell development and persistence in most barrier tissues in mice, including the intestine [9,54]. In humans, however, Hobit is not differentially expressed in $\mathrm{T}_{\mathrm{RM}}$ cells versus circulating $\mathrm{CD} 8^{+} \mathrm{T}$ cells and, thus, may not be specific for $\mathrm{T}_{\mathrm{RM}}$ cells [92]. Runx3 is a central regulator of $\mathrm{T}_{\mathrm{RM}}$ differentiation and supports the expression of genes related to tissue residence, such as Cd69 and Itgae, but also Gzmb, while suppressing the expression of genes involved in cell egress, including Klf2, S1pr1 and Ccr7 [60]. The differential expression of the two transcription factors Blimp1 and Id3 was used to identify the functional diversity within the SI IEL CD8 ${ }^{+} \mathrm{T}$ cells, induced by an LCMV infection in mice [55]. Early after LCMV infection, Blimp1 expression was increased in KLRG $1{ }^{\text {hi } / \text { int }} \mathrm{CD} 127^{\mathrm{lo}}$ cells, which also showed the expression of genes associated with effector functions of $T_{R M}$ cells, such as elevated levels of granzyme B. On the other hand, KLRG ${ }^{\mathrm{lo}} \mathrm{CD} 127^{\mathrm{hi}}$ small intestinal $\mathrm{CD}^{+} \mathrm{T}$ cells expressed high levels of Id3 rather than Blimp1 and they shared their transcriptional signatures with the other memory, or memory-like, cells, including $\mathrm{T}_{\mathrm{CM}}$ and $\mathrm{T}_{\mathrm{FH}}$ cells in the effector phase and $\mathrm{T}_{\mathrm{RM}}$ cells in the memory phase of infection. Id $3^{\text {hi }}$ Blimp ${ }^{\text {lo }}$ KLRG $1^{\text {lo }} \mathrm{CD} 127^{\text {hi }}$ had enhanced memory potential and, upon recall infection, they rapidly proliferated and generated a great frequency of resident and re-circulating cells [55].

The development of $T_{\mathrm{RM}}$ cells in barrier tissues is also affected by dietary components. As an example, the aryl hydrocarbon receptor (Ahr) is an essential regulator in maintaining IEL numbers in the skin [93] and the intestine [66]. Intestinal Ahr signaling is regulated by dietary products (e.g. cruciferous vegetable-derived products, glucosinolate glucobrassicin I3C) and environmental pollutants, but also by microbiota-derived Trp-catabolites that act as an Ahr ligand (indole-3-aldehyde, indole acrylic acid, indole acetic acid or tryptamine from $L$. reuteri and many other Firmicutes including members of the Clostridium genus) [66,94,95]. In the intestinal mucosa Ahr signaling appears to be critical for maintaining an intact epithelial barrier, including the retention of intestinal IEL, notably TCR $\gamma \delta^{+} \mathrm{T}$ cells. As a consequence, the absence of Ahr ligands causes a change in the luminal microbial load and composition, and increased signs of immunopathological changes in the epithelium [66]. Furthermore, Ahr-deficient mice develop exacerbated dextran-sodium sulfate (DSS)-induced colitis with elevated expression of pro-inflammatory cytokine genes (e.g., IL-1 $\beta$, IL-6, TNF- $\alpha$, when compared to DSS-treated, Ahr-sufficient wildtype mice [96]. Intriguingly, in patients with IBD, particularly in patients with CD, AhR signaling in intestinal tissues is downregulated [97].

Due to their preferential localization within the barrier tissues, $T_{R M}$ cells generally have restricted access to nutrients and oxygen compared to circulating $T$ cells. Thus, $T_{R M}$ cells generally live under rather stressful conditions and, hence, show a series of particular metabolic adaptations-for example, fatty acid oxidation - to survive and function in the tissues. For this purpose, $T_{\mathrm{RM}}$ cells express organ-specific isoforms of fatty acid-binding 
proteins (FABP) for the selective uptake of fatty acids. Small intestinal CD8 ${ }^{+} \mathrm{T}_{\mathrm{RM}}$ IEL express fabp1, fabp2 and fabp6, but very low fabp4 and fabp5, known to be expressed by skin $\mathrm{T}_{\mathrm{RM}}$ cells $[67,98,99]$.

The enhanced mitochondrial fitness and functions seen in $\mathrm{T}_{\mathrm{RM}}$ cells contribute to their maintenance and effector cell activity. As an example, the transcription factor Bhlhe40 was shown to maintain the mitochondrial fitness and metabolism of $T_{R M}$ cells and tumor infiltrating cells (TIL), where the expression of Bhlhe40 is selectively upregulated [42,67]. This promotes an active chromatin state for $\mathrm{T}_{\mathrm{RM}}$ cell and TIL residency and functionality. The enhanced mitochondrial fitness may help to overcome the local stress factors present in the microenvironment (e.g., limited access to nutrients, such as glucose) under hypoxic or oxidative conditions [100]. The purinergic receptor P2RX7 is required for the establishment, maintenance and functionality of long-lived tissue-resident and central memory $\mathrm{CD} 8^{+} \mathrm{T}$ cell populations in mice. These receptors promote mitochondrial homeostasis and metabolic function in differentiating memory $\mathrm{CD} 8^{+} \mathrm{T}$ cells, at least in part by inducing AMP-activated protein kinase, which activates glucose and fatty acid uptake and oxidation when cellular energy is low, as is the case for $\mathrm{T}_{\mathrm{RM}}$ cells in barrier tissues [101]. P2RX7expressing cells, however, are also highly susceptible to extracellular ATP (eATP) and NAD-induced cell death (NICD) [69], which becomes particularly evident upon ex vivo isolation of these cell populations from solid tissues, where the released NAD and eATP will lead to their underrepresentation due to NICD during subsequent adoptive cell transfer, or extended in vitro cell cultures. This likely results in an underestimation of their role in systemic immunoprotection, as assessed by adoptive transfer experiments, where-in the absence of ARTC2.2-specific nanobodies during the ex vivo isolation procedure-an overwhelming portion of transferred cells will undergo rapid NAD-induced cell death $[69,102]$ (Ch. Mueller and Leslie Saurer, unpublished observations). Hence, some of the $\mathrm{T}_{\mathrm{RM}}$ cell transfer experiments reported in the literature where NICD was not blocked may need to be repeated to fully reveal the potential of $\mathrm{T}_{\mathrm{RM}}$ cell-mediated immunoprotection also inand outside their site of residence.

\section{5. $T_{R M}$ Cell Dynamics during Infection}

As outlined above, $\mathrm{T}_{\mathrm{RM}}$ cells, at least under homeostatic conditions, do not generally recirculate and reside preferentially in nonlymphoid tissues, particularly at barrier sites, but occasionally also in lymph nodes and the spleen or local vascular compartments [103]. The most recent data obtained with Hobit fate mapping mice [104], skin transplant experiments [105] and with long-term parabionts [106] reveal a distinct view of the biology and the impact of $T_{R M}$ cells also for systemic immune responses. Immunosurveillance by $C D 8^{+} T_{R M}$ cells is mostly ascribed to the rapid elimination of infected cells either via cytotoxic activity by producing cytotoxic granule-associated proteins such as granzymes and perforin or by directly, or indirectly, recruiting effector cells via chemokines or inflammatory cytokines $[2,26]$. Moreover, skin and intestinal infection models revealed that $\mathrm{CD}^{+} \mathrm{T}_{\mathrm{RM}}$ cells can exit peripheral tissues and recirculate during a secondary $\mathrm{T}$ cell response, as so-called "ex- $\mathrm{T}_{\mathrm{RM}}$ " cells (Figure 1). This egress of reactivated T cells from nonlymphoid tissues is partially mediated by S1P, since FTY720 treatment reduced the number of $\mathrm{CD}^{+} 9^{+} \mathrm{T}_{\mathrm{RM}}$ cells in the draining lymph nodes [104,105]. In a fate mapping mouse line, Hobit reporter tdT-positive cells also expressed YFP expression, and once Hobit expression was lost, YFP remained, allowing the identification of ex-Hobit ${ }^{+}$cells, which are "ex- $\mathrm{T}_{\mathrm{RM}}$ " cells [104]. Upon intestinal reinfection, Hobit ${ }^{+} \mathrm{CD} 8^{+} \mathrm{T}_{\mathrm{RM}}$ cells are able to expand in the peripheral tissue and draining lymph nodes, and recirculate. These "ex- $\mathrm{T}_{\mathrm{RM}}$ " cells have decreased Hobit expression and acquire a $\mathrm{T}_{\mathrm{EM}}$ phenotype, mostly $\mathrm{CD}_{2} \mathrm{~L}^{-} \mathrm{KLRG}^{+} \mathrm{CX} 3 \mathrm{CR} 1^{+}$. Downregulation of Hobit may directly influence $\mathrm{T}_{\mathrm{RM}}$ cell egress and differentiation into circulating cells, as these cells lack the expression of tissue retention molecules (for example, CD69) and express Klf2 and S1pr1, which support tissue egress [104]. After skin transplantation from ovalbumin-expressing vesicular stomatitis virus infected mice and local reactivation by a SIINFEKL peptide delivered by a tattoo gun, 
$\mathrm{T}_{\mathrm{RM}}$ cells also egress from the skin into the circulation. At the transcriptome level, intestinal $\mathrm{T}_{\mathrm{RM}}$ cells show a signature distinct from $\mathrm{T}_{\mathrm{CM}}$ and $\mathrm{T}_{\mathrm{EM}}$ cells, indicating that they are indeed functionally separate cell populations, although they share some epigenetics signatures. In a multipotency scoring system, ranging from 0 (exhausted CD8 ${ }^{+} \mathrm{T}$ cells) to 1 (naïve $\mathrm{CD}^{+}$cells), the plasticity score of $\mathrm{T}_{\mathrm{RM}}$ cells was between the scores for $\mathrm{T}_{\mathrm{CM}}$ and $\mathrm{T}_{\mathrm{EM}}$ cells, suggesting that $\mathrm{T}_{\mathrm{RM}}$ cells are indeed not fully differentiated yet and retain a certain level of plasticity [105]. Hence, upon antigen-specific reactivation, "ex- $\mathrm{T}_{\mathrm{RM}}$ " cells can differentiate into $\mathrm{T}_{\mathrm{CM}}$ and $\mathrm{T}_{\mathrm{EM}}$ cells, but can also generate further $\mathrm{T}_{\mathrm{RM}}$ cells, thus contributing to a systemic immune response [82,105]. Upon repeated antigen exposure, e.g., following local reinfection with the same pathogen, also "ex- $\mathrm{T}_{\mathrm{RM}}$ " cells are observed, with downregulated CD69 and CD103 on their cell surface, however maintaining most of the T cell signature of their tissue of origin (CCR9 in intestinal TRM cells) [105].

In contrast to the other studies mentioned above, extended parabiosis experiments showed the presence of circulating "ex- $\mathrm{T}_{\mathrm{RM}}$ " cells after primary infection. During 30 days of parabiosis, donor and host cells were equilibrated in blood, and 200 days following their physical separation, a higher percentage of host cells than donor cells was found in the peripheral blood, indicating that they originated from cells that were not able to equilibrate during parabiosis, most likely cells within the tissues ( $\mathrm{T}_{\mathrm{RM}}$ cells) that later rejoined the circulation ("ex- $\mathrm{T}_{\mathrm{RM}}$ " cells), giving rise to memory cells in blood (Figure 1). Collectively, it appears that $\mathrm{T}$ cells which adapted a $\mathrm{T}_{\mathrm{RM}}$ cell lifestyle within non-lymphoid organs, rather than circulating adaptive immune cells, represent the main cellular players for the maintenance of local immunosurveillance, while de novo haematopoiesis still contributes to systemic immunosurveillance, but becomes of decreasing relevance in this process of progressive decentralization of the maintenance at the level of the organism [106]. This shift in the relevance of primary versus secondary and tertiary lymphoid tissues with age is also reflected by the sharp decline in the thymic output of T cells after puberty [107].

Most of these $\mathrm{T}_{\mathrm{RM}}$ cell - and "ex- $\mathrm{T}_{\mathrm{RM}}$ " cell concepts were initially established in mouse models of infections; however, they have been also described in other disease models.

\section{6. $T_{R M}$ Cells in Intestinal Inflammation}

After pathogen clearance following acute infection, antigen-specific $\mathrm{T}_{\mathrm{RM}}$ cells persist locally and can rapidly eliminate the pathogen upon reinfection. Unlike in acute infections, in chronic inflammatory diseases of the intestinal tract the triggering antigens (e.g., luminal microbiota- or diet-derived antigens) can persist and lead to chronic or intermittent stimulation of the local immune system, notably of antigen-specific $\mathrm{T}_{\mathrm{RM}}$ cells. In recent years, evidence has been increasing for a critical contribution of $\mathrm{T}_{\mathrm{RM}}$ cells in the pathogenesis of intestinal relapsing-remitting inflammatory disorders, including CeD and IBD. These diseases may be triggered by the presence of the T cell-activating antigens in the absence of appropriate immunoregulatory mechanisms, or intact epithelial barriers. In CeD, the same antigens, i.e., gluten-derived peptides, and hence also the same long-lived disease-causing $\mathrm{T}$ cell clones, are involved [12]. On the other hand, in IBD, the relative abundance of disease-triggering antigens may substantially differ in the different phases of remission and relapsing disease, as evidenced by the result of an extensive $16 \mathrm{~S}$ sequencing of intestinal mucosa-associated bacteria in patients with active and inactive IBD [108].

Intriguingly, in $\mathrm{CeD}$ patients, circulating gluten-specific $\mathrm{CD} 4^{+} \mathrm{T}$ cells with a unique cell surface signature $\left(\mathrm{CD} 38^{+}, \mathrm{CD}^{+}{ }^{+}, \mathrm{CXCR}^{+}, \mathrm{PD} 1^{+}, \mathrm{ICOS}^{+}, \mathrm{CD} 161^{+}, \mathrm{CCR}^{+}\right.$and $\mathrm{CD} 28^{+}$) were observed to show a high resemblance to gluten-specific $\mathrm{CD} 4^{+} \mathrm{T}$ cells found in the affected small intestinal mucosa, but also to $\mathrm{CD}^{+} \mathrm{T}$ cells in patients with systemic lupus erythematosus [109]. This distinct cell-surface signature of circulating autoinflammatory $\mathrm{CD}^{+} \mathrm{T}$ cells also overlaps with the signature previously described in patients with rheumatoid arthritis [110]. This strongly suggests that there is indeed a distinct, but rather rare, subset of $\mathrm{CD}^{+} \mathrm{T}$ cells which is common to several $\mathrm{CD}^{+} \mathrm{T}$ cell-dependent autoinflammatory disorders. Whether these circulating gluten-specific $\mathrm{CD}^{+} \mathrm{T}$ cells indeed represent circulating "ex- $\mathrm{T}_{\mathrm{RM}}$ cells" which originated in the small intestinal mucosa of patients with 
CeD remains open. Likewise, it remains to be seen whether the appearance of circulating cells with this distinct cell surface signature can be used to predict imminent flares of chronic relapsing-remitting disorders.

In $\mathrm{CeD}$, the main trigger of active disease is the dietary gluten exposure; thus, a continued gluten-free diet represents an effective treatment. Although gluten-specific $\mathrm{CD} 4^{+} \mathrm{T}$ cell clonotypes decrease following gluten avoidance therapy, some gluten-specific $\mathrm{CD} 4^{+} \mathrm{T}$ cells still persist for decades in the intestine and blood. These long-lived gluten-specific $\mathrm{CD}^{+} \mathrm{T}$ cells can be reactivated by re-exposure to even traces of gluten [12]. Further corroborating these findings on the longevity of $\mathrm{CD} 4^{+} \mathrm{T}$ cells in the small intestine, Bartolomé-Casado and collaborators have shown that in the human transplanted small intestine, both $\mathrm{CD}^{+}$and $\mathrm{CD}^{+} \mathrm{T}_{\mathrm{RM}}$ cells persist in the tissue for more than 1 year. After their in vitro restimulation, a large proportion of lamina propria $\mathrm{CD} 103^{+} \mathrm{CD}^{+} \mathrm{T}$ cells produced granzyme $\mathrm{B}$, perforin and one or more of the cytokines tested (IFN- $\gamma$, IL-2, TNF- $\alpha$ ), outnumbering granzyme $\mathrm{B}$, perforin and inflammatory cytokine-expressing T cells in the other $\mathrm{CD} 8^{+} \mathrm{T}$ cell subsets (CD103 ${ }^{+}$IEL and CD103- LPL). Similarly, upon restimulation in vitro, small intestinal $\mathrm{CD} 103^{+} \mathrm{CD}^{+} \mathrm{T}$ cells also produced granzyme $\mathrm{B}$ and displayed a polyfunctional $\mathrm{T}_{\mathrm{H}} 1$ cell profile, while a minor proportion of $\mathrm{CD}_{103}{ }^{+} \mathrm{CD} 4^{+} \mathrm{T}$ cells produced IL-17 $[57,58]$.

In IBD, both $\mathrm{CD}^{+}$and $\mathrm{CD} 8^{+} \mathrm{T}$ cells can be associated with the induction and progression of the disease. In colonic samples from $\mathrm{UC}$ and $\mathrm{CD}$ patients, increased frequencies of $\mathrm{CD} 103^{+} \mathrm{CD} 9^{+}$cells are seen, which show higher expression of pro-inflammatory genes (Ifng, Il13, Il17A, Tnfa) than colonic CD69- $\mathrm{T}$ cells. Moreover, both $\mathrm{CD} 4^{+} \mathrm{CD} 69^{+}$and $\mathrm{CD}^{+} \mathrm{CD} 9^{+} \mathrm{T}_{\mathrm{RM}}$ cells were enriched in these biopsies. Elevated frequencies of phenotypic $\mathrm{CD}^{+} \mathrm{T}_{\mathrm{RM}}$ cells were associated with shorter flare-free intervals, while such an association was not found for phenotypic $\mathrm{CD} 8^{+} \mathrm{T}_{\mathrm{RM}}$ cells [9].

In the $\mathrm{T}$ cell transfer mouse model of colitis, the transfer of $\mathrm{CD} 4^{+} \mathrm{T}$ cells lacking both Hobit and Blimp-1, which are two transcription factors associated with mouse $\mathrm{T}_{\mathrm{RM}}$ cells, into lymphopenic Rag2 ${ }^{-/}$mice was not able to induce colitis to the same extent as with wildtype $\mathrm{CD}^{+}{ }^{+} \mathrm{T}$ cell transfer. Furthermore, mice that received Hobit/Blimp-1 double knockout $\mathrm{CD}^{+} \mathrm{T}$ cells showed reduced leukocyte recruitment and attenuated expression of pro-inflammatory cytokines. Hobit/Blimp-1 double knockout mice are also protected from acute TNBS-induced colitis and acute and chronic DSS-induced colitis. Additionally, DTR-mediated ablation of transferred $\mathrm{Hobit}^{+} \mathrm{CD}^{+} \mathrm{T}$ cells protected recipient mice from colitis induction [9]. In the colon of $\mathrm{CD}$ patients, $\mathrm{CD} 69^{+} \mathrm{CCR} 7^{+} \mathrm{CD} 4^{+} \mathrm{T}_{\mathrm{RM}}$ cells are enriched and produce higher levels of IL-17A and TNF- $\alpha$ than controls [111]. In line with the fact that the microbiota can be involved in the pathogenesis of IBD, colonic-resident $\mathrm{CD} 4^{+} \mathrm{T}$ cells reactive to enteric bacteria presented increased IL-17A production in both CD and UC patients regardless of disease activity or therapy [11]. Moreover, we recently established a mouse model of reversible $\mathrm{CD} 4^{+} \mathrm{T}$ cell transfer colitis, which allowed us to study the role of $\mathrm{CD}^{+} \mathrm{T}$ cells in disease onset. In this model, remission could be induced by systemic anti$\mathrm{CD} 4 \mathrm{mAb}$ treatment, depleting the circulating $\mathrm{CD}^{+} \mathrm{T}$ cells, and after treatment stopped, mice relapsed spontaneously, indicating a potential role of tissue-resident $\mathrm{CD} 4^{+} \mathrm{T}_{\mathrm{RM}}$ cells not only in colitis induction but also in relapsing disease, which may have escaped anti-CD4 mAb-mediated depletion [112,113].

Single-cell RNA and TCR sequencing analyses of $C D 8^{+} T_{R M}$ cells in the rectum of patients with active $\mathrm{UC}$, and normal control tissues, revealed four different $\mathrm{CD} 8^{+} \mathrm{T}_{\mathrm{RM}}$ cell clusters. Intriguingly, TCR clonotypes were shared among cells from these four clusters. This may indicate a functional plasticity of $C D 8^{+} \mathrm{T}_{\mathrm{RM}}$ cells. Furthermore, in the peripheral blood of patients with active $\mathrm{UC}$, an increased number of $\mathrm{CD}^{+}$cells were found that were clonally related to this cluster of $\mathrm{CD}^{+} \mathrm{T}_{\mathrm{RM}}$ cells, which was also enriched in the affected rectum. Hence, this may indicate the existence of circulating "ex-CD8 ${ }^{+} \mathrm{T}_{\mathrm{RM}}$ " cells [105] also in patients with active IBD. The $\mathrm{CD}^{+} \mathrm{T}$ cells of this cluster present in both the affected rectum and the peripheral blood of patients with active UC expressed higher levels of genes encoding proteins with inflammatory or cytolytic functions and showed prominent expression of Eomes mRNA. Using the LCMV infection model in mice, the same 
authors further demonstrated that Eomes regulates a number of downstream genes, such as Ifng, Gzma, Klrg1, Icos (inflammatory cytokines, cytolytic granules, chemokines, molecules that promote survival, killer cell lectin receptors, costimulatory molecules and trafficking molecules) in intestinal antigen-specific T cells sorted from the IEL compartment. Thus, these findings suggest that intestinal $\mathrm{CD} 8^{+} \mathrm{T}_{\mathrm{RM}}$ cells in UC patients upregulate Eomes and may thus be prone to potentially differentiate into pathogenic $\mathrm{T}$ cells with an increased inflammatory and cytolytic profile [10]. This tentative identification of circulating "ex- $\mathrm{T}_{\mathrm{RM}}$ " cells also during active UC may further represent an opportunity to use the appearance of "ex- $\mathrm{T}_{\mathrm{RM}}$ " cells in the peripheral blood of patients as an early marker of an imminent relapse of the disease. In rheumatoid arthritis, circulating pathogenic $\mathrm{CD}^{+} \mathrm{T}$ cells with the same gene signature as their tissue were also described, suggesting that they represent "ex- $\mathrm{T}_{\mathrm{RM}}$ cells" [114] At present, it is not known yet whether circulating "ex-CD4 ${ }^{+} \mathrm{T}_{\mathrm{RM}}$ " cells are present in patients with active IBD.

$\mathrm{T}_{\mathrm{RM}}$ cells express inhibitory receptors, such as PD-1 or CTLA-4 [115]. This may lead to severe immune-related adverse effects in cancer patients treated with immune checkpoint inhibitors (ICI), notably ICI-induced colitis [116]. Indeed, a recent report elegantly demonstrated the distinct accumulation of activated IFN- $\gamma$ overexpressing $\mathrm{CD} 103^{+} \mathrm{CD} 69^{+} \mathrm{CD} 8^{+}$ $\mathrm{T}_{\mathrm{RM}}$ cells in the colon of patients who developed ICI-induced colitis following either antiCTLA-4/PD-1 combination therapy or anti-PD-1 inhibitor therapy. The colitis-promoting activity of the IFN- $\gamma$ producing $C D 8^{+} T_{R M}$ cells was successfully treated by the application of a JAK inhibitor, tofacitinib [117].

\section{7. $T_{R M}$ Cells as Potential Therapeutic Targets in Remitting-Relapsing Intestinal Diseases}

In addition to widely used biologicals targeting inflammatory cytokines, including TNF or IL-12/23, therapies targeting the trafficking of disease-inducing and exacerbating effector cells is becoming an attractive concept as an additional option for patients with active IBD [118]. Immune cell trafficking comprises all the aspects of adhesion, homing, retention and circulation of the immune cells. There are ongoing efforts and progress to design therapeutic anti-trafficking agents (ATA) and to apply them in the clinic. $\mathrm{T}_{\mathrm{RM}}$ cells could be the key player in responding to the ATAs, although their mechanisms of action are poorly identified. For instance, recently, a phase III trial in IBD patients was completed, where the anti- $\beta 7$ integrin antibody etrolizumab was administered [119]. Etrolizumab binds the beta7 integrin, which can form heterodimers with the alphaE (CD103) or alpha 4 (Itga4) integrin chain, thus affecting the binding of T cells to E-cadherin and/or MadCAM-1, respectively [120]. These results indicate that this treatment may indeed attenuate the accumulation of $\mathrm{T}_{\mathrm{RM}}$ cells in the intestinal mucosa and/or gut by the impaired recruitment of $\beta 7$-integrin expressing leukocytes including $\mathrm{CD} 4^{+}$and $\mathrm{CD} 8^{+}$ $\mathrm{T}$ cells. Similarly, vedolizumab (anti- $\alpha 4 \beta 7$ ), which was approved by the FDA and the European Medicines Agency, and ontamalimab (anti MAdCAM1; phase II trial) block T cell homing to the gut by inhibiting the binding of the $\alpha 4 \beta 7$ integrin to the MAdCAM- 1 addressin on endothelial cells at mucosal sites, particularly the intestinal mucosa: this is expected to reduce the recruitment of and seeding of circulating $\mathrm{T}_{\mathrm{RM}}$ cells (including "ex$\mathrm{T}_{\mathrm{RM}}$ cells") [121-123]. Another class of ATAs directly target $\mathrm{S}^{\mathrm{P}} \mathrm{P}_{1}$ pathway (e.g., ozanimod, estrasimod, amiselimod) and are currently under investigation for treating patients with IBD $[124,125]$. As mentioned above, complete $\mathrm{S1P}_{1}$ downregulation is one of the key features of intestinal $\mathrm{T}_{\mathrm{RM}}$ cells' differentiation from $\mathrm{S}_{1} \mathrm{P}_{1}$ hi effector $\mathrm{T}$ cells. Thus, one of the mechanisms of action of those drugs targeting $\mathrm{S}_{1} \mathrm{P}_{1}$ could be the inhibition of the homing of precursor cells to the gut and, as a result, the decrease of the de novo $\mathrm{T}_{\mathrm{RM}}$ cell differentiation, which might contribute to maintaining patients in remission.

Chemokine receptor signaling pathways represent an additional target strategy to interfere with leukocyte trafficking in patients with chronic inflammatory disorders. As an example, vercirnon (also named CCX282-B) is an orally active small-molecule (CCX-282-B) CCR9 antagonist that inhibits CCR9-mediated $\mathrm{Ca}^{2+}$ mobilization and CCL25-directed chemotaxis in vitro in gut-specific T cells [126]. Vercirnon was tested as a potential treat- 
ment for patients with CD in a phase III clinical study (SHIELD 1 study). However, in patients with moderately-to-severely active $\mathrm{CD}$, an improvement in clinical response as the primary endpoint and the key secondary endpoint of remission was not achieved [127].

Furthermore, targeting disease-inducing antigen-specific $\mathrm{T}_{\mathrm{RM}}$ cells for treatment might become feasible with novel approaches such as epitope-specific immunotherapy. As an intriguing example, taking advantage of the identified disease-inducing gluten-derived epitopes in patients with CeD [12], Nexvax2 was designed as a peptide-based, epitopespecific therapeutic vaccine aimed at inducing $\mathrm{CD} 4^{+} \mathrm{T}$ tolerance towards dietary gluten and preventing the relapse of the disease after gluten consumption in patients with $\mathrm{CeD}$. In a phase 1 clinical trial, adjuvant-free Nexvax2, a mixture of three immunodominant gluten peptides, was administered intradermally in gradually ascending doses to HLA-DQ2.5 $5^{+}$ $\mathrm{CeD}$ patients with disease remission and in a gluten-free diet. After oral gluten challenge, targeted $\mathrm{CD}^{+} \mathrm{T}$ cells did not secrete IFN- $\gamma$ in response to the specific antigen in vitro and the duodenal mucosal histology was improved in vaccinated patients [128]. However, such an approach may not be suitable for disorders with a multitude of disease-triggering antigens, as is the case in patients with IBD, where the composition of the intestinal microbiome, and, hence, the repertoire of luminal antigens present in the intestinal mucosa, may change dramatically during distinct phases of the disease [108].

\section{Conclusions and Outlook}

The relevance of $T_{R M}$ cells in the efficient local immunoprotection against infectious agents, and for the control of solid tumor growth [129], but also for relevant T cell-mediated chronic relapsing-remitting autoinflammatory diseases, such as multiple sclerosis, rheumatoid arthritis, psoriasis, inflammatory bowel diseases and celiac disease, has become a main focus in current research activities. Initially, $\mathrm{T}_{\mathrm{RM}}$ cells were considered to be strictly non-migrating $\mathrm{T}$ cell subsets - mostly based on short-term parabiosis experiments $[52,130]$. More recently, evidence was found for the developmental plasticity also of $\mathrm{T}_{\mathrm{RM}}$ cells as, upon restimulation, they may be able to enter the circulation and may affect systemic immunity in a most significant manner [104,106]. Intriguingly, during their non-resident stage, they still maintain a tropism for homing back to their site of origin [105]. This propensity of $\mathrm{T}_{\mathrm{RM}}$ cells to enter the circulation may be further enhanced when the antigen-specific activation occurs during inflammatory conditions, notably for intestinal CD8 $\alpha \alpha^{+} \mathrm{TCR} \alpha \beta^{+}$ IEL (Hoheisel-Dickgreber, Ch. Mueller, unpublished). At present, the mechanisms that regulate the retention versus the migration of $\mathrm{T}_{\mathrm{RM}}$ cells are only incompletely understood. Differential expression of integrins, but also of proteins that regulate the chemotactic responsiveness, including CD69, and members of the RGS family, may be candidates for contributing to this change of lifestyle by $\mathrm{T}$ cells.

The field of research in $\mathrm{T}_{\mathrm{RM}}$ cell biology, notably of IEL cell subsets, was hampered for some time with difficulties associated with the adoptive transfer of ex vivo isolated $\mathrm{T}$ cell subsets into a new host. For example, often, the transferred cells could not be retrieved; similarly, during in vitro cultures, they rapidly died; and in long-term cultures, the phenotypic composition of these surviving $\mathrm{T}$ cells differed substantially from the input population of cells. With the availability of nanobodies against ARTC2.2, many of these difficulties are overcome [69] and it remains to be seen how this technical advance will affect our concepts of these $\mathrm{T}_{\mathrm{RM}}$ cells prone to NICD following ex vivo isolation.

It remains to be seen whether the appearance of $T_{R M}$ cells also in the circulation may allow monitoring of the peripheral blood of patients for the presence of $\mathrm{T}$ cells with a signature reminiscent of $\mathrm{T}_{\mathrm{RM}}$ cells as a predictor of an imminent relapse of IBD. In this context, Sebastian Zundler and co-workers reported that high frequencies of CD103 ${ }^{+}$ $\mathrm{CD} 9^{+} \mathrm{CD} 4^{+} \mathrm{T}_{\mathrm{RM}}$ cells in the intestinal lamina propria of patients with IBD were associated with a shorter flare-free interval [9]. Since some of these "ex- $\mathrm{T}_{\mathrm{RM}}$ " cells may have the propensity to home back to their initial site of residence as $T_{R M}$ cells, interfering with the adherence and migration of these disease-driving $\mathrm{T}$ cells into the intestinal sites (and also to extraintestinal sites where they may cause extraintestinal manifestations of IBD), they 
might represent also a therapeutic modality $[9,119,131]$. The onset of clinical flare-up in T-cell-mediated relapsing-remitting inflammatory disorders is controlled by several factors, including the availability of the triggering antigen(s), and the functional differentiation of the responding $\mathrm{T}$ cells. To determine how the functional capacities of antigen-specific $\mathrm{T}$ cells evolve, studying the functional capacities of antigen-specific $\mathrm{T}$ cells (e.g., using gluten peptide HLA class II tetramers in celiac disease as (so far) the only chronic relapsingremitting auto-inflammatory disorder with a known antigen) has been most instructive in providing insight into the functions and the phenotype of (auto-) antigen-specific $T$ cells in various compartments. These findings may now also be exploited to follow putative autoinflammatory $\mathrm{T}$ cell subsets in the tissue and in the circulation also in auto-inflammatory chronic diseases with a multitude of disease-triggering antigens, as exemplified in patients with IBD. Patients with IBD showing enormous quantitative and qualitative changes in the intestinal mucosa-associated microbiome, as assessed by $16 \mathrm{~S}$ rRNA sequencing, during remission vs. active flares of the disease, which may not only affect the ensuing immune response by the antigen repertoire expressed, but also by the kind of microbiomeproduced metabolites, e.g., short-chain fatty acids or Ahr agonists [108]. In these instances, combining TCR spectratyping and phenotypic/functional characterization by scRNAseq of serial tissue or blood samples may help to define the plasticity versus stability of the functional phenotype of $\mathrm{T}$ cell clones which may be involved in triggering relapses of the disease.

Collectively, studies on the pathophysiological role of $\mathrm{T}_{\mathrm{RM}}$ cells in immunosurveillance and protection and tumor immunity, but also as key mediators of immunopathologies, notably chronic relapsing-remitting disorders, has gained tremendous momentum. Moreover, technical advances, which may further allow us to combine single-cell analyses with the spatiotemporal distribution of distinct cells (and their mutual interactions) in the tissue, at unprecedented granularity, are likely to yield novel insights that will allow us to design novel therapeutic interventions for targeting the specific drivers of these debilitating disorders.

Author Contributions: Conceptualization and writing—review and editing, J.B.d.A., C.M. and B.G. All authors have read and agreed to the published version of the manuscript.

Funding: Cited work by the authors is funded by the Swiss National Science Foundation (grant\# 189277 and 170084).

Conflicts of Interest: The authors declare no conflict of interest.

\section{References}

1. Mackay, L.K.; Wynne-Jones, E.; Freestone, D.; Pellicci, D.G.; Mielke, L.A.; Newman, D.M.; Braun, A.; Masson, F.; Kallies, A.; Belz, G.T.; et al. T-Box Transcription Factors Combine with the Cytokines TGF- $\beta$ and IL-15 to Control Tissue-Resident Memory T Cell Fate. Immunity 2015, 43, 1101-1111. [CrossRef] [PubMed]

2. Kumar, B.V.; Ma, W.; Miron, M.; Granot, T.; Guyer, R.S.; Carpenter, D.J.; Senda, T.; Sun, X.; Ho, S.-H.; Lerner, H.; et al. Human Tissue-Resident Memory T Cells Are Defined by Core Transcriptional and Functional Signatures in Lymphoid and Mucosal Sites. Cell Rep. 2017, 20, 2921-2934. [CrossRef]

3. Kurd, N.S.; He, Z.; Louis, T.L.; Milner, J.J.; Omilusik, K.D.; Jin, W.; Tsai, M.S.; Widjaja, C.E.; Kanbar, J.N.; Olvera, J.G.; et al. Early Precursors and Molecular Determinants of Tissue-Resident Memory CD8+ T Lymphocytes Revealed by Single-Cell RNA Sequencing. Sci. Immunol. 2020, 5, eaaz6894. [CrossRef] [PubMed]

4. FitzPatrick, M.E.B.; Provine, N.M.; Garner, L.C.; Powell, K.; Amini, A.; Irwin, S.L.; Ferry, H.; Ambrose, T.; Friend, P.; Vrakas, G.; et al. Human Intestinal Tissue-Resident Memory T Cells Comprise Transcriptionally and Functionally Distinct Subsets. Cell Rep. 2021, 34, 108661. [CrossRef] [PubMed]

5. Samat, A.A.K.; van der Geest, J.; Vastert, S.J.; van Loosdregt, J.; van Wijk, F. Tissue-Resident Memory T Cells in Chronic Inflammation-Local Cells with Systemic Effects? Cells 2021, 10, 409. [CrossRef] [PubMed]

6. Tokura, Y.; Phadungsaksawasdi, P.; Kurihara, K.; Fujiyama, T.; Honda, T. Pathophysiology of Skin Resident Memory T Cells. Front. Immunol. 2021, 11, 618897. [CrossRef]

7. Hirahara, K.; Kokubo, K.; Aoki, A.; Kiuchi, M.; Nakayama, T. The Role of CD4 ${ }^{+}$Resident Memory T Cells in Local Immunity in the Mucosal Tissue-Protection Versus Pathology-. Front. Immunol. 2021, 12, 616309. [CrossRef] [PubMed]

8. Okła, K.; Farber, D.L.; Zou, W. Tissue-Resident Memory T Cells in Tumor Immunity and Immunotherapy. J. Exp. Med. 2021, 218, e20201605. [CrossRef] 
9. Zundler, S.; Becker, E.; Spocinska, M.; Slawik, M.; Parga-Vidal, L.; Stark, R.; Wiendl, M.; Atreya, R.; Rath, T.; Leppkes, M.; et al. Hobit- and Blimp-1-Driven CD4+ Tissue-Resident Memory T Cells Control Chronic Intestinal Inflammation. Nat. Immunol. 2019, 20, 288-300. [CrossRef]

10. Boland, B.S.; He, Z.; Tsai, M.S.; Olvera, J.G.; Omilusik, K.D.; Duong, H.G.; Kim, E.S.; Limary, A.E.; Jin, W.; Milner, J.J.; et al. Heterogeneity and Clonal Relationships of Adaptive Immune Cells in Ulcerative Colitis Revealed by Single-Cell Analyses. Sci. Immunol. 2020, 5, eabb4432. [CrossRef] [PubMed]

11. Hegazy, A.N.; West, N.R.; Stubbington, M.J.T.; Wendt, E.; Suijker, K.I.M.; Datsi, A.; This, S.; Danne, C.; Campion, S.; Duncan, S.H.; et al. Circulating and Tissue-Resident $\mathrm{CD} 4^{+} \mathrm{T}$ Cells With Reactivity to Intestinal Microbiota Are Abundant in Healthy Individuals and Function Is Altered During Inflammation. Gastroenterology 2017, 153, 1320-1337.e16. [CrossRef]

12. Risnes, L.F.; Christophersen, A.; Dahal-Koirala, S.; Neumann, R.S.; Sandve, G.K.; Sarna, V.K.; Lundin, K.E.A.; Qiao, S.-W.; Sollid, L.M. Disease-Driving CD4 ${ }^{+}$T Cell Clonotypes Persist for Decades in Celiac Disease. J. Clin. Investig. 2018, 128, 2642-2650. [CrossRef] [PubMed]

13. Alatab, S.; Sepanlou, S.G.; Ikuta, K.; Vahedi, H.; Bisignano, C.; Safiri, S.; Sadeghi, A.; Nixon, M.R.; Abdoli, A.; Abolhassani, H.; et al. The Global, Regional, and National Burden of Inflammatory Bowel Disease in 195 Countries and Territories, 1990-2017: A Systematic Analysis for the Global Burden of Disease Study 2017. Lancet Gastroenterol. Hepatol. 2020, 5, 17-30. [CrossRef]

14. Sairenji, T.; Collins, K.L.; Evans, D.V. An Update on Inflammatory Bowel Disease. Prim. Care Clin. Off. Pract. 2017, 44, 673-692. [CrossRef] [PubMed]

15. Wallace, K.L.; Zheng, L.B.; Kanazawa, Y.; Shih, D.Q. Immunopathology of Inflammatory Bowel Disease. World J. Gastroenterol. 2014, 20, 6-17. [CrossRef]

16. De Souza, H.S.P.; Fiocchi, C. Immunopathogenesis of IBD: Current State of the Art. Nat. Rev. Gastroenterol. 2015, 13, 13-27. [CrossRef] [PubMed]

17. Hazel, K.; O'Connor, A. Emerging Treatments for Inflammatory Bowel Disease. Ther. Adv. Chronic Dis. 2020, 11, 2040622319899297. [CrossRef] [PubMed]

18. Abraham, C.; Cho, J.H. Inflammatory Bowel Disease. N. Engl. J. Med. 2009, 361, 2066-2078. [CrossRef] [PubMed]

19. Bernstein, C.N.; Blanchard, J.F.; Rawsthorne, P.; Yu, N. The Prevalence of Extraintestinal Diseases in Inflammatory Bowel Disease: A Population-Based Study. Am. J. Gastroenterol. 2001, 96, 1116-1122. [CrossRef]

20. Vavricka, S.R.; Schoepfer, A.; Scharl, M.; Lakatos, P.L.; Navarini, A.; Rogler, G. Extraintestinal Manifestations of Inflammatory Bowel Disease. Inflamm. Bowel Dis. 2015, 21, 1982-1992. [CrossRef]

21. Rogler, G.; Luc, B.; Biedermann, L.; Scharl, M. New Insights into the Pathophysiology of Inflammatory Bowel Disease: Microbiota, Epigenetics and Common Signalling Pathways. Swiss Med. Wkly. 2018, 148, w14599. [CrossRef]

22. Sollid, L.M.; Lie, B.A. Celiac Disease Genetics: Current Concepts and Practical Applications. Clin. Gastroenterol. Hepatol. 2005, 3 , 843-851. [CrossRef]

23. Green, P.H.R.; Cellier, C. Celiac Disease. N. Engl. J. Med. 2007, 357, 1731-1743. [CrossRef]

24. Sollid, L.M.; Tye-Din, J.A.; Qiao, S.-W.; Anderson, R.P.; Gianfrani, C.; Koning, F. Update 2020: Nomenclature and Listing of Celiac Disease-Relevant Gluten Epitopes Recognized by CD4+ T Cells. Immunogenetics 2020, 72, 85-88. [CrossRef] [PubMed]

25. Iwata, M.; Iwata, M.; Hirakiyama, A.; Hirakiyama, A.; Eshima, Y.; Eshima, Y.; Kagechika, H.; Kagechika, H.; Kato, C.; Kato, C.; et al. Retinoic Acid Imprints Gut-Homing Specificity on T Cells. Immunity 2004, 21, 527-538. [CrossRef]

26. Masopust, D.; Soerens, A.G. Tissue-Resident T Cells and Other Resident Leukocytes. Annu. Rev. Immunol. 2019, 37. [CrossRef] [PubMed]

27. Schenkel, J.M.; Masopust, D. Tissue-Resident Memory T Cells. Immunity 2014, 41, 886-897. [CrossRef]

28. Schenkel, J.M.; Fraser, K.A.; Beura, L.K.; Pauken, K.E.; Vezys, V.; Masopust, D. T Cell Memory. Resident Memory CD8 T Cells Trigger Protective Innate and Adaptive Immune Responses. Science 2014, 346, 98-101. [CrossRef]

29. Casey, K.A.; Fraser, K.A.; Schenkel, J.M.; Moran, A.; Abt, M.C.; Beura, L.K.; Lucas, P.J.; Artis, D.; Wherry, E.J.; Hogquist, K.; et al. Antigen-Independent Differentiation and Maintenance of Effector-like Resident Memory T Cells in Tissues. J. Immunol. 2012, 188, 4866-4875. [CrossRef]

30. Cheroutre, H.; Cheroutre, H. IELs: Enforcing Law and Order in the Court of the Intestinal Epithelium. Immunol. Rev. 2005, 206, 114-131. [CrossRef] [PubMed]

31. Grand, D.G.; Bensussan, N.C.; Malissen, B.; Seris, M.M.; Briottet, C.; Vassalli, P. Two Gut Intraepithelial CD8+ Lymphocyte Populations with Different T Cell Receptors: A Role for the Gut Epithelium in T Cell Differentiation. J. Exp. Med. 1991, 173, 471-481. [CrossRef]

32. Cheroutre, H.; Lambolez, F.; Mucida, D. The Light and Dark Sides of Intestinal Intraepithelial Lymphocytes. Nat. Rev. Immunol. 2011, 11, 445-456. [CrossRef]

33. Shires, J.; Theodoridis, E.; Hayday, A.C. Biological Insights into TCRgammadelta+ and TCRalphabeta+ Intraepithelial Lymphocytes Provided by Serial Analysis of Gene Expression (SAGE). Immunity 2001, 15, 419-434. [CrossRef]

34. Mowat, A.M.; Agace, W.W. Regional Specialization within the Intestinal Immune System. Nat. Rev. Immunol. 2014, 14, 667-685. [CrossRef]

35. Takamura, S. Niches for the Long-Term Maintenance of Tissue-Resident Memory T Cells. Front. Immunol. 2018, 9, 1214. [CrossRef]

36. Agace, W.W.; McCoy, K.D. Regionalized Development and Maintenance of the Intestinal Adaptive Immune Landscape. Immunity 2017, 46, 532-548. [CrossRef] 
37. Macpherson, A.J.; Slack, E.; Geuking, M.B.; McCoy, K.D. The Mucosal Firewalls against Commensal Intestinal Microbes. Semin. Immunopathol. 2009, 31, 145-149. [CrossRef] [PubMed]

38. Gerlach, C.; van Heijst, J.W.J.; Swart, E.; Sie, D.; Armstrong, N.; Kerkhoven, R.M.; Zehn, D.; Bevan, M.J.; Schepers, K.; Schumacher, T.N.M. One Naive T Cell, Multiple Fates in CD8+ T Cell Differentiation. J. Exp. Med. 2010, 207, 1235-1246. [CrossRef] [PubMed]

39. Stemberger, C.; Huster, K.M.; Koffler, M.; Anderl, F.; Schiemann, M.; Wagner, H.; Busch, D.H. A Single Naive CD8+ T Cell Precursor Can Develop into Diverse Effector and Memory Subsets. Immunity 2007, 27, 985-997. [CrossRef] [PubMed]

40. Plumlee, C.R.; Obar, J.J.; Colpitts, S.L.; Jellison, E.R.; Haining, W.N.; Lefrancois, L.; Khanna, K.M. Early Effector CD8 T Cells Display Plasticity in Populating the Short-Lived Effector and Memory-Precursor Pools Following Bacterial or Viral Infection. Sci. Rep. 2015, 5, 12264. [CrossRef]

41. Kaech, S.M.; Tan, J.T.; Wherry, E.J.; Konieczny, B.T.; Surh, C.D.; Ahmed, R. Selective Expression of the Interleukin 7 Receptor Identifies Effector CD8 T Cells That Give Rise to Long-Lived Memory Cells. Nat. Immunol. 2003, 4, 1191-1198. [CrossRef] [PubMed]

42. Mackay, L.K.; Rahimpour, A.; Ma, J.Z.; Collins, N.; Stock, A.T.; Hafon, M.-L.; Vega-Ramos, J.; Lauzurica, P.; Mueller, S.N.; Stefanovic, T.; et al. The Developmental Pathway for CD103(+)CD8+ Tissue-Resident Memory T Cells of Skin. Nat. Immunol. 2013, 14, 1294-1301. [CrossRef] [PubMed]

43. King, C.G.; Koehli, S.; Hausmann, B.; Schmaler, M.; Zehn, D.; Palmer, E. T Cell Affinity Regulates Asymmetric Division, Effector Cell Differentiation, and Tissue Pathology. Immunity 2012, 37, 709-720. [CrossRef] [PubMed]

44. Kaech, S.M.; Wherry, E.J. Heterogeneity and Cell-Fate Decisions in Effector and Memory CD8+ T Cell Differentiation during Viral Infection. Immunity 2007, 27, 393-405. [CrossRef] [PubMed]

45. Fiege, J.K.; Stone, I.A.; Fay, E.J.; Markman, M.W.; Wijeyesinghe, S.; Macchietto, M.G.; Shen, S.; Masopust, D.; Langlois, R.A. The Impact of TCR Signal Strength on Resident Memory T Cell Formation during Influenza Virus Infection. J. Immunol. 2019, 203, 936-945. [CrossRef]

46. Mani, V.; Bromley, S.K.; Äijö, T.; Mora-Buch, R.; Carrizosa, E.; Warner, R.D.; Hamze, M.; Sen, D.R.; Chasse, A.Y.; Lorant, A.; et al. Migratory DCs Activate TGF- $\beta$ to Precondition Naïve CD8+ T Cells for Tissue-Resident Memory Fate. Science 2019, 366 , eaav5728. [CrossRef]

47. Sheridan, B.S.; Pham, Q.-M.; Lee, Y.-T.; Cauley, L.S.; Puddington, L.; Lefrançois, L. Oral Infection Drives a Distinct Population of Intestinal Resident Memory CD8+ T Cells with Enhanced Protective Function. Immunity 2014, 40, 747-757. [CrossRef]

48. Bergsbaken, T.; Bevan, M.J.; Fink, P.J. Local Inflammatory Cues Regulate Differentiation and Persistence of CD8+ Tissue-Resident Memory T Cells. Cell Rep. 2017, 19, 114-124. [CrossRef] [PubMed]

49. Jiang, X.; Clark, R.A.; Liu, L.; Wagers, A.J.; Fuhlbrigge, R.C.; Kupper, T.S. Skin Infection Generates Non-Migratory Memory CD8+ TRM Cells Providing Global Skin Immunity. Nature 2012, 483, 227-231. [CrossRef]

50. Schenkel, J.M.; Fraser, K.A.; Vezys, V.; Masopust, D. Sensing and Alarm Function of Resident Memory CD8+ T Cells. Nat. Immunol. 2013, 14, 509-513. [CrossRef]

51. Klonowski, K.D.; Williams, K.J.; Marzo, A.L.; Blair, D.A.; Lingenheld, E.G.; Lefrançois, L. Dynamics of Blood-Borne CD8 Memory T Cell Migration In Vivo. Immunity 2004, 20, 551-562. [CrossRef]

52. Poussier, P.; Edouard, P.; Lee, C.; Binnie, M.; Julius, M. Thymus-Independent Development and Negative Selection of T Cells Expressing T Cell Receptor Alpha/Beta in the Intestinal Epithelium: Evidence for Distinct Circulation Patterns of Gut- and Thymus-Derived T Lymphocytes. J. Exp. Med. 1992, 176, 187-199. [CrossRef]

53. Mueller, S.N.; Mackay, L.K. Tissue-Resident Memory T Cells: Local Specialists in Immune Defence. Nat. Rev. Immunol. 2015, 16, 79-89. [CrossRef]

54. Mackay, L.K.; Minnich, M.; Kragten, N.A.M.; Liao, Y.; Nota, B.; Seillet, C.; Zaid, A.; Man, K.; Preston, S.; Freestone, D.; et al. Hobit and Blimp1 Instruct a Universal Transcriptional Program of Tissue Residency in Lymphocytes. Science 2016, 352, 459-463. [CrossRef] [PubMed]

55. Milner, J.J.; Toma, C.; He, Z.; Kurd, N.S.; Nguyen, Q.P.; McDonald, B.; Quezada, L.; Widjaja, C.E.; Witherden, D.A.; Crowl, J.T.; et al. Heterogenous Populations of Tissue-Resident CD8+ T Cells Are Generated in Response to Infection and Malignancy. Immunity 2020, 52, 808-824.e7. [CrossRef]

56. Landrith, T.A.; Sureshchandra, S.; Rivera, A.; Jang, J.C.; Rais, M.; Nair, M.G.; Messaoudi, I.; Wilson, E.H. CD103+ CD8 T Cells in the Toxoplasma-Infected Brain Exhibit a Tissue-Resident Memory Transcriptional Profile. Front. Immunol. 2017, 8, 335. [CrossRef] [PubMed]

57. Bartolomé-Casado, R.; Landsverk, O.J.B.; Chauhan, S.K.; Richter, L.; Phung, D.; Greiff, V.; Risnes, L.F.; Yao, Y.; Neumann, R.S.; Yaqub, S.; et al. Resident Memory CD8 T Cells Persist for Years in Human Small Intestine. J. Exp. Med. 2019, 216, $2412-2426$. [CrossRef] [PubMed]

58. Bartolomé-Casado, R.; Landsverk, O.J.B.; Chauhan, S.K.; Sætre, F.; Hagen, K.T.; Yaqub, S.; Øyen, O.; Horneland, R.; Aandahl, E.M.; Aabakken, L.; et al. CD4+ T Cells Persist for Years in the Human Small Intestine and Display a TH1 Cytokine Profile. Mucosal Immunol. 2021, 14, 402-410. [CrossRef] [PubMed]

59. Mackay, L.K.; Braun, A.; Macleod, B.L.; Collins, N.; Tebartz, C.; Bedoui, S.; Carbone, F.R.; Gebhardt, T. Cutting Edge: CD69 Interference with Sphingosine-1-Phosphate Receptor Function Regulates Peripheral T Cell Retention. J. Immunol. 2015, 194, 2059-2063. [CrossRef] 
60. Milner, J.J.; Toma, C.; Yu, B.; Zhang, K.; Omilusik, K.; Phan, A.T.; Wang, D.; Getzler, A.J.; Nguyen, T.; Crotty, S.; et al. Runx3 Programs CD8+ T Cell Residency in Non-Lymphoid Tissues and Tumours. Nature 2017, 107, 1-23. [CrossRef]

61. Skon, C.N.; Lee, J.-Y.; Anderson, K.G.; Masopust, D.; Hogquist, K.A.; Jameson, S.C. Transcriptional Downregulation of S1pr1 Is Required for the Establishment of Resident Memory CD8+ T Cells. Nat. Immunol. 2013, 14, 1285-1293. [CrossRef]

62. Bergsbaken, T.; Bevan, M.J. Proinflammatory Microenvironments within the Intestine Regulate the Differentiation of TissueResident CD8 ${ }^{+}$T Cells Responding to Infection. Nat. Immunol. 2015, 16, 406-414. [CrossRef]

63. Romagnoli, P.A.; Fu, H.H.; Qiu, Z.; Khairallah, C.; Pham, Q.M.; Puddington, L.; Khanna, K.M.; Lefrançois, L.; Sheridan, B.S. Differentiation of Distinct Long-Lived Memory CD4 T Cells in Intestinal Tissues after Oral Listeria Monocytogenes Infection. Mucosal Immunol. 2017, 10, 520-530. [CrossRef] [PubMed]

64. Cheuk, S.; Schlums, H.; Sérézal, I.G.; Martini, E.; Chiang, S.C.; Marquardt, N.; Gibbs, A.; Detlofsson, E.; Introini, A.; Forkel, M.; et al. CD49a Expression Defines Tissue-Resident CD8+ T Cells Poised for Cytotoxic Function in Human Skin. Immunity 2017, 46, 287-300. [CrossRef] [PubMed]

65. Gibbons, D.L.; Gibbons, D.L.; Gibbons, D.L.; Abeler-Dorner, L.; Abeler-Dörner, L.; Abeler-Dorner, L.; Raine, T.; Raine, T.; Raine, T.; Hwang, I.Y.; et al. Cutting Edge: Regulator of G Protein Signaling-1 Selectively Regulates Gut T Cell Trafficking and Colitic Potential. J. Immunol. 2011, 187, 2067-2071. [CrossRef]

66. Li, Y.; Innocentin, S.; Withers, D.R.; Roberts, N.A.; Gallagher, A.R.; Grigorieva, E.F.; Wilhelm, C.; Veldhoen, M. Exogenous Stimuli Maintain Intraepithelial Lymphocytes via Aryl Hydrocarbon Receptor Activation. Cell 2011, 147, 629-640. [CrossRef] [PubMed]

67. Li, C.; Zhu, B.; Son, Y.M.; Wang, Z.; Jiang, L.; Xiang, M.; Ye, Z.; Beckermann, K.E.; Wu, Y.; Jenkins, J.W.; et al. The Transcription Factor Bhlhe40 Programs Mitochondrial Regulation of Resident CD8+ T Cell Fitness and Functionality. Immunity 2019, 51, 491-507.e7. [CrossRef]

68. Rissiek, B.; Lukowiak, M.; Raczkowski, F.; Magnus, T.; Mittrücker, H.-W.; Koch-Nolte, F. In Vivo Blockade of Murine ARTC2.2 During Cell Preparation Preserves the Vitality and Function of Liver Tissue-Resident Memory T Cells. Front. Immunol. 2018, 9 , 1580. [CrossRef] [PubMed]

69. da Silva, H.B.; Wang, H.; Qian, L.J.; Qian, L.J.; Hogquist, K.A.; Jameson, S.C. ARTC2.2/P2RX7 Signaling during Cell Isolation Distorts Function and Quantification of Tissue-Resident CD8+ T Cell and Invariant NKT Subsets. J. Immunol. 2019, 202, $2153-2163$. [CrossRef]

70. Hashimoto-Hill, S.; Friesen, L.; Kim, M.; Kim, C.H. Contraction of Intestinal Effector T Cells by Retinoic Acid-Induced Purinergic Receptor P2X7. Mucosal Immunol. 2017, 10, 912-923. [CrossRef]

71. Sun, L.; Li, T.; Tang, H.; Yu, K.; Ma, Y.; Yu, M.; Qiu, Y.; Xu, P.; Xiao, W.; Yang, H. Intestinal Epithelial Cells-Derived HypoxiaInducible Factor- $1 \alpha$ Is Essential for the Homeostasis of Intestinal Intraepithelial Lymphocytes. Front. Immunol. 2019, 10, 806. [CrossRef]

72. Kilshaw, P.J.; Murant, S.J. A New Surface Antigen on Intraepithelial Lymphocytes in the Intestine. Eur. J. Immunol. 1990, 20, 2201-2207. [CrossRef]

73. Siddiqui, K.R.R.; Laffont, S.; Powrie, F. E-Cadherin Marks a Subset of Inflammatory Dendritic Cells That Promote T Cell-Mediated Colitis. Immunity 2010, 32, 557-567. [CrossRef]

74. Bromley, S.K.; Akbaba, H.; Mani, V.; Mora-Buch, R.; Chasse, A.Y.; Sama, A.; Luster, A.D. CD49a Regulates Cutaneous Resident Memory CD8+ T Cell Persistence and Response. Cell Rep. 2020, 32, 108085. [CrossRef]

75. Cyster, J.G.; Schwab, S.R. Sphingosine-1-Phosphate and Lymphocyte Egress from Lymphoid Organs. Immunology 2012, 30, 69-94. [CrossRef]

76. Bankovich, A.J.; Shiow, L.R.; Cyster, J.G. CD69 Suppresses Sphingosine 1-Phosophate Receptor-1 (S1P1) Function through Interaction with Membrane Helix 4. J. Biol. Chem. 2010, 285, 22328-22337. [CrossRef]

77. Masopust, D.; Schenkel, J.M. The Integration of T Cell Migration, Differentiation and Function. Nat. Rev. Immunol. 2013, 13, 309-320. [CrossRef]

78. Walsh, D.A.; da Silva, H.B.; Beura, L.K.; Peng, C.; Hamilton, S.E.; Masopust, D.; Jameson, S.C. The Functional Requirement for CD69 in Establishment of Resident Memory CD8+T Cells Varies with Tissue Location. J. Immunol. 2019, 203, 946-955. [CrossRef] [PubMed]

79. Papadakis, K.A.; Prehn, J.; Nelson, V.; Cheng, L.; Binder, S.W.; Ponath, P.D.; Andrew, D.P.; Targan, S.R. The Role of ThymusExpressed Chemokine and Its Receptor CCR9 on Lymphocytes in the Regional Specialization of the Mucosal Immune System. J. Immunol. 2000, 165, 5069-5076. [CrossRef] [PubMed]

80. Fu, H.; Jangani, M.; Parmar, A.; Wang, G.; Coe, D.; Spear, S.; Sandrock, I.; Capasso, M.; Coles, M.; Cornish, G.; et al. A Subset of CCL25-Induced Gut-Homing T Cells Affects Intestinal Immunity to Infection and Cancer. Front. Immunol. 2019, 10, 271. [CrossRef] [PubMed]

81. McCully, M.L.; Ladell, K.; Andrews, R.; Jones, R.E.; Miners, K.L.; Roger, L.; Baird, D.M.; Cameron, M.J.; Jessop, Z.M.; Whitaker, I.S.; et al. CCR8 Expression Defines Tissue-Resident Memory T Cells in Human Skin. J. Immunol. 2018, 200, 1639-1650. [CrossRef]

82. Behr, F.M.; Kragten, N.A.M.; Wesselink, T.H.; Nota, B.; van Lier, R.A.W.; Amsen, D.; Stark, R.; Hombrink, P.; van Gisbergen, K.P.J.M. Blimp-1 Rather Than Hobit Drives the Formation of Tissue-Resident Memory CD8+ T Cells in the Lungs. Front. Immunol. 2019, 10, 400. [CrossRef]

83. Swarnalekha, N.; Schreiner, D.; Litzler, L.C.; Iftikhar, S.; Kirchmeier, D.; Künzli, M.; King, C.G. Redefining CD4 T Cell Residency: Helper T Cells Orchestrate Protective Humoral Immunity in the Lung. BioRxiv 2020. [CrossRef] 
84. Doedens, A.L.; Rubinstein, M.P.; Gross, E.T.; Best, J.A.; Craig, D.H.; Baker, M.K.; Cole, D.J.; Bui, J.D.; Goldrath, A.W. Molecular Programming of Tumor-Infiltrating CD8+ T Cells and IL15 Resistance. Cancer Immunol. Res. 2016, 4, 799-811. [CrossRef]

85. Zheng, C.; Zheng, L.; Yoo, J.-K.; Guo, H.; Zhang, Y.; Guo, X.; Kang, B.; Hu, R.; Huang, J.Y.; Zhang, Q.; et al. Landscape of Infiltrating T Cells in Liver Cancer Revealed by Single-Cell Sequencing. Cell 2017, 169, 1342-1356.e16. [CrossRef] [PubMed]

86. Masuho, I.; Balaji, S.; Muntean, B.S.; Skamangas, N.K.; Chavali, S.; Tesmer, J.J.G.; Babu, M.M.; Martemyanov, K.A. A Global Map of G Protein Signaling Regulation by RGS Proteins. Cell 2020, 183, 503-521.e19. [CrossRef]

87. Kehrl, J.H. The Impact of RGS and Other G-Protein Regulatory Proteins on Gai-Mediated Signaling in Immunity. Biochem. Pharmacol. 2016, 114, 40-52. [CrossRef]

88. Travis, M.A.; Sheppard, D. TGF- $\beta$ Activation and Function in Immunity. Annu. Rev. Immunol. 2014, 32, 51-82. [CrossRef]

89. Mohammed, J.; Beura, L.K.; Bobr, A.; Astry, B.; Chicoine, B.; Kashem, S.W.; Welty, N.E.; Igyártó, B.Z.; Wijeyesinghe, S.; Thompson, E.A.; et al. Stromal Cells Control the Epithelial Residence of DCs and Memory T Cells by Regulated Activation of TGF- $\beta$. Nat. Immunol. 2016, 17, 414-421. [CrossRef] [PubMed]

90. Hirai, T.; Yang, Y.; Zenke, Y.; Li, H.; Chaudhri, V.K.; Diaz, J.S.D.L.C.; Zhou, P.Y.; Nguyen, B.A.-T.; Bartholin, L.; Workman, C.J.; et al. Competition for Active TGF $\beta$ Cytokine Allows for Selective Retention of Antigen-Specific Tissue- Resident Memory T Cells in the Epidermal Niche. Immunity 2021, 54, 84-98.e5. [CrossRef]

91. Schenkel, J.M.; Fraser, K.A.; Casey, K.A.; Beura, L.K.; Pauken, K.E.; Vezys, V.; Masopust, D. IL-15-Independent Maintenance of Tissue-Resident and Boosted Effector Memory CD8 T Cells. J. Immunol. 2016, 196, 3920-3926. [CrossRef]

92. Braga, F.A.V.; Hertoghs, K.M.L.; Kragten, N.A.M.; Doody, G.M.; Barnes, N.A.; Remmerswaal, E.B.M.; Hsiao, C.; Moerland, P.D.; Wouters, D.; Derks, I.A.M.; et al. Blimp-1 Homolog Hobit Identifies Effector-type Lymphocytes in Humans. Eur. J. Immunol. 2015, 45, 2945-2958. [CrossRef]

93. Zaid, A.; Mackay, L.K.; Rahimpour, A.; Braun, A.; Veldhoen, M.; Carbone, F.R.; Manton, J.H.; Heath, W.R.; Mueller, S.N. Persistence of Skin-Resident Memory T Cells within an Epidermal Niche. Proc. Natl. Acad. Sci. USA 2014, 111, 5307-5312. [CrossRef] [PubMed]

94. Lamas, B.; Natividad, J.M.; Sokol, H. Aryl Hydrocarbon Receptor and Intestinal Immunity. Mucosal Immunol. 2018, 11, 1-15. [CrossRef]

95. Gandhi, R.; Kumar, D.; Burns, E.J.; Nadeau, M.; Dake, B.; Laroni, A.; Kozoriz, D.; Weiner, H.L.; Quintana, F.J. Activation of the Aryl Hydrocarbon Receptor Induces Human Type 1 Regulatory T Cell-like and Foxp3+ Regulatory T Cells. Nat. Immunol. 2010, 11, 846-853. [CrossRef]

96. Wang, Q.; Yang, K.; Han, B.; Sheng, B.; Yin, J.; Pu, A.; Li, L.; Sun, L.; Yu, M.; Qiu, Y.; et al. Aryl Hydrocarbon Receptor Inhibits Inflammation in DSS-Induced Colitis via the MK2/p-MK2/TTP Pathway. Int. J. Mol. Med. 2018, 41, 868-876. [CrossRef]

97. Monteleone, I.; Rizzo, A.; Sarra, M.; Sica, G.; Sileri, P.; Biancone, L.; MacDonald, T.T.; Pallone, F.; Monteleone, G. Aryl Hydrocarbon Receptor-Induced Signals Up-Regulate IL-22 Production and Inhibit Inflammation in the Gastrointestinal Tract. Gastroenterology 2011, 141, 237-248.e1. [CrossRef] [PubMed]

98. Pan, Y.; Tian, T.; Park, C.O.; Lofftus, S.Y.; Mei, S.; Liu, X.; Luo, C.; O’Malley, J.T.; Gehad, A.; Teague, J.E.; et al. Survival of Tissue-Resident Memory T Cells Requires Exogenous Lipid Uptake and Metabolism. Nature 2017, 543, 252-256. [CrossRef] [PubMed]

99. Frizzell, H.; Fonseca, R.; Christo, S.N.; Evrard, M.; Cruz-Gomez, S.; Zanluqui, N.G.; von Scheidt, B.; Freestone, D.; Park, S.L.; McWilliam, H.E.G.; et al. Organ-Specific Isoform Selection of Fatty Acid-Binding Proteins in Tissue-Resident Lymphocytes. Sci. Immunol. 2020, 5, eaay9283. [CrossRef]

100. Colgan, S.P.; Campbell, E.L.; Kominsky, D.J. Hypoxia and Mucosal Inflammation. Annu. Rev. Pathol. Mech. Dis. 2016, 11, 77-100. [CrossRef] [PubMed]

101. Lin, S.-C.; Hardie, D.G. AMPK: Sensing Glucose as Well as Cellular Energy Status. Cell Metab. 2018, 27, 299-313. [CrossRef]

102. Künzli, M.; Schreiner, D.; Pereboom, T.C.; Swarnalekha, N.; Litzler, L.C.; Lötscher, J.; Ertuna, Y.I.; Roux, J.; Geier, F.; Jakob, R.P.; et al. Long-Lived T Follicular Helper Cells Retain Plasticity and Help Sustain Humoral Immunity. Sci. Immunol. 2020, 5, eaay5552. [CrossRef]

103. Jameson, S.C.; Masopust, D. Understanding Subset Diversity in T Cell Memory. Immunity 2018, 48, 214-226. [CrossRef] [PubMed]

104. Behr, F.M.; Parga-Vidal, L.; Kragten, N.A.M.; van Dam, T.J.P.; Wesselink, T.H.; Sheridan, B.S.; Arens, R.; van Lier, R.A.W.; Stark, R.; van Gisbergen, K.P.J.M. Tissue-Resident Memory CD8+ T Cells Shape Local and Systemic Secondary T Cell Responses. Nat. Immunol. 2020, 21, 1070-1081. [CrossRef] [PubMed]

105. Fonseca, R.; Beura, L.K.; Quarnstrom, C.F.; Ghoneim, H.E.; Fan, Y.; Zebley, C.C.; Scott, M.C.; Fares-Frederickson, N.J.; Wijeyesinghe, S.; Thompson, E.A.; et al. Developmental Plasticity Allows Outside-in Immune Responses by Resident Memory T Cells. Nat. Immunol. 2020, 21, 412-421. [CrossRef] [PubMed]

106. Wijeyesinghe, S.; Beura, L.K.; Pierson, M.J.; Stolley, J.M.; Adam, O.A.; Ruscher, R.; Steinert, E.M.; Rosato, P.C.; Vezys, V.; Masopust, D. Expansible Residence Decentralizes Immune Homeostasis. Nature 2021, 592, 457-462. [CrossRef] [PubMed]

107. Palmer, D.B. The Effect of Age on Thymic Function. Front. Immunol. 2013, 4, 316. [CrossRef]

108. Yilmaz, B.; Øyås, O.; Ramon, C.; Bravo, F.D.; Fournier, N.; Michetti, P.; Mueller, C.; Geuking, M.; Pittet, V.E.H.; Rogler, G.; et al. Microbial Network Disturbances in Relapsing Refractory Crohn's Disease. Nat. Med. 2019, 25, 1-34. [CrossRef] [PubMed] 
109. Christophersen, A.; Lund, E.G.; Snir, O.; Solà, E.; Kanduri, C.; Dahal-Koirala, S.; Zühlke, S.; Molberg, Ø.; Utz, P.J.; RohaniPichavant, M.; et al. Distinct Phenotype of CD4+ T Cells Driving Celiac Disease Identified in Multiple Autoimmune Conditions. Nat. Med. 2019, 25, 734-737. [CrossRef]

110. Rao, D.A.; Gurish, M.F.; Marshall, J.L.; Slowikowski, K.; Fonseka, C.Y.; Liu, Y.; Donlin, L.T.; Henderson, L.A.; Wei, K.; Mizoguchi, F.; et al. Pathologically Expanded Peripheral T Helper Cell Subset Drives B Cells in Rheumatoid Arthritis. Nature 2017, 542, 110-114. [CrossRef]

111. Bishu, S.; Zaatari, M.E.; Hayashi, A.; Hou, G.; Bowers, N.; Kinnucan, J.; Manoogian, B.; Muza-Moons, M.; Zhang, M.; Grasberger, H.; et al. CD4+ Tissue-Resident Memory T Cells Expand and Are a Major Source of Mucosal Tumour Necrosis Factor $\alpha$ in Active Crohn's Disease. J. Crohn's Colitis 2019, 13, 905-915. [CrossRef]

112. Chung, C.K.K.; Brasseit, J.; Althaus-Steiner, E.; Rihs, S.; Mueller, C. Mouse Model of Reversible Intestinal Inflammation. BioProtocol 2017, 7, e2173. [CrossRef]

113. Brasseit, J.; Althaus-Steiner, E.; Faderl, M.; Dickgreber, N.; Saurer, L.; Genitsch, V.; Dolowschiak, T.; Li, H.; Finke, D.; Hardt, W.-D.; et al. CD4 T Cells Are Required for Both Development and Maintenance of Disease in a New Mouse Model of Reversible Colitis. Mucosal Immunol. 2016, 9, 689-701. [CrossRef]

114. Spreafico, R.; Rossetti, M.; van Loosdregt, J.; Wallace, C.A.; Massa, M.; Magni-Manzoni, S.; Gattorno, M.; Martini, A.; Lovell, D.J.; Albani, S. A Circulating Reservoir of Pathogenic-like CD4+ T Cells Shares a Genetic and Phenotypic Signature with the Inflamed Synovial Micro-Environment. Ann. Rheum. Dis. 2016, 75, 459. [CrossRef] [PubMed]

115. Park, S.L.; Zaid, A.; Hor, J.L.; Christo, S.N.; Prier, J.E.; Davies, B.; Alexandre, Y.O.; Gregory, J.L.; Russell, T.A.; Gebhardt, T.; et al. Local Proliferation Maintains a Stable Pool of Tissue-Resident Memory T Cells after Antiviral Recall Responses. Nat. Immunol. 2018, 19, 183-191. [CrossRef] [PubMed]

116. Larkin, J.; Chiarion-Sileni, V.; Gonzalez, R.; Grob, J.J.; Cowey, C.L.; Lao, C.D.; Schadendorf, D.; Dummer, R.; Smylie, M.; Rutkowski, P.; et al. Combined Nivolumab and Ipilimumab or Monotherapy in Untreated Melanoma. N. Engl. J. Med. 2015, 373, 23-34. [CrossRef] [PubMed]

117. Sasson, S.C.; Slevin, S.M.; Cheung, V.T.F.; Nassiri, I.; Olsson-Brown, A.; Fryer, E.; Ferreira, R.C.; Trzupek, D.; Gupta, T.; AlHillawi, L.; et al. IFN $\gamma$-Producing CD8+ Tissue Resident Memory T Cells Are a Targetable Hallmark of Immune Checkpoint Inhibitor-Colitis. Gastroenterology 2021. [CrossRef]

118. Zundler, S.; Neurath, M.F. Novel Insights into the Mechanisms of Gut Homing and Antiadhesion Therapies in Inflammatory Bowel Diseases. Inflamm. Bowel Dis. 2017, 23, 617-627. [CrossRef]

119. Committee, T.E.G.S.; Sandborn, W.J.; Vermeire, S.; Tyrrell, H.; Hassanali, A.; Lacey, S.; Tole, S.; Tatro, A.R. Etrolizumab for the Treatment of Ulcerative Colitis and Crohn's Disease: An Overview of the Phase 3 Clinical Program. Adv. Ther. 2020, 37, 3417-3431. [CrossRef]

120. Lichnog, C.; Klabunde, S.; Becker, E.; Fuh, F.; Tripal, P.; Atreya, R.; Klenske, E.; Erickson, R.; Chiu, H.; Reed, C.; et al. Cellular Mechanisms of Etrolizumab Treatment in Inflammatory Bowel Disease. Front. Pharmacol. 2019, 10, 39. [CrossRef]

121. Hassan-Zahraee, M.; Banerjee, A.; Cheng, J.B.; Zhang, W.; Ahmad, A.; Page, K.; von Schack, D.; Zhang, B.; Martin, S.W.; Nayak, S.; et al. Anti-MAdCAM Antibody Increases SS7+ T Cells and CCR9 Gene Expression in the Peripheral Blood of Patients With Crohn's Disease. J. Crohn's Colitis 2017, 12, 77-86. [CrossRef]

122. Sandborn, W.J.; Feagan, B.G.; Rutgeerts, P.; Hanauer, S.; Colombel, J.-F.; Sands, B.E.; Lukas, M.; Fedorak, R.N.; Lee, S.; Bressler, B.; et al. Vedolizumab as Induction and Maintenance Therapy for Crohn's Disease. N. Engl. J. Med. 2013, 369, 711-721. [CrossRef]

123. Feagan, B.G.; Rutgeerts, P.; Sands, B.E.; Hanauer, S.; Colombel, J.-F.; Sandborn, W.J.; Assche, G.V.; Axler, J.; Kim, H.-J.; Danese, S.; et al. Vedolizumab as Induction and Maintenance Therapy for Ulcerative Colitis. N. Engl. J. Med. 2013, 369, 699-710. [CrossRef]

124. Sugahara, K.; Maeda, Y.; Shimano, K.; Mogami, A.; Kataoka, H.; Ogawa, K.; Hikida, K.; Kumagai, H.; Asayama, M.; Yamamoto, T.; et al. Amiselimod, a Novel Sphingosine 1-phosphate Receptor-1 Modulator, Has Potent Therapeutic Efficacy for Autoimmune Diseases, with Low Bradycardia Risk. Brit. J. Pharmacol. 2017, 174, 15-27. [CrossRef]

125. Sandborn, W.J.; Feagan, B.G.; Wolf, D.C.; D’Haens, G.; Vermeire, S.; Hanauer, S.B.; Ghosh, S.; Smith, H.; Cravets, M.; Frohna, P.A.; et al. Ozanimod Induction and Maintenance Treatment for Ulcerative Colitis. N. Engl. J. Med. 2016, 374, 1754-1762. [CrossRef] [PubMed]

126. Walters, M.J.; Wang, Y.; Lai, N.; Baumgart, T.; Zhao, B.N.; Dairaghi, D.J.; Bekker, P.; Ertl, L.S.; Penfold, M.E.T.; Jaen, J.C.; et al. Characterization of CCX282-B, an Orally Bioavailable Antagonist of the CCR9 Chemokine Receptor, for Treatment of Inflammatory Bowel Disease. J. Pharmacol. Exp. Ther. 2010, 335, 61-69. [CrossRef] [PubMed]

127. Feagan, B.G.; Sandborn, W.J.; D’Haens, G.; Lee, S.D.; Allez, M.; Fedorak, R.N.; Seidler, U.; Vermeire, S.; Lawrance, I.C.; Maroney, A.C.; et al. Randomised Clinical Trial: Vercirnon, an Oral CCR9 Antagonist, vs. Placebo as Induction Therapy in Active Crohn's Disease. Aliment. Pharmacol. Ther. 2015, 42, 1170-1181. [CrossRef]

128. Goel, G.; King, T.; Daveson, A.J.; Andrews, J.M.; Krishnarajah, J.; Krause, R.; Brown, G.J.E.; Fogel, R.; Barish, C.F.; Epstein, R.; et al. Epitope-Specific Immunotherapy Targeting CD4-Positive T Cells in Coeliac Disease: Two Randomised, Double-Blind, Placebo-Controlled Phase 1 Studies. Lancet Gastroenterol. Hepatol. 2017, 2, 479-493. [CrossRef]

129. Nizard, M.; Roussel, H.; Diniz, M.O.; Karaki, S.; Tran, T.; Voron, T.; Dransart, E.; Sandoval, F.; Riquet, M.; Rance, B.; et al. Induction of Resident Memory T Cells Enhances the Efficacy of Cancer Vaccine. Nat. Commun. 2017, 8, 15221. [CrossRef] [PubMed] 
130. Steinert, E.M.; Schenkel, J.M.; Fraser, K.A.; Beura, L.K.; Manlove, L.S.; Igyártó, B.Z.; Southern, P.J.; Masopust, D. Quantifying Memory CD8 T Cells Reveals Regionalization of Immunosurveillance. Cell 2015, 161, 737-749. [CrossRef]

131. Dotan, I.; Allez, M.; Danese, S.; Keir, M.; Tole, S.; McBride, J. The Role of Integrins in the Pathogenesis of Inflammatory Bowel Disease: Approved and Investigational Anti-integrin Therapies. Med. Res. Rev. 2020, 40, 245-262. [CrossRef] [PubMed] 